\title{
Spatial variability of phytoplankton pigment distributions in the Subtropical South Pacific Ocean: comparison between in situ and predicted data
}

\author{
J. $\operatorname{Ras}^{1,2}$, H. Claustre ${ }^{1,2}$, and J. Uitz ${ }^{1,2, *}$ \\ ${ }^{1}$ UPMC Univ Paris 06, UMR 7093, Lab. d'Océanographie de Villefranche sur mer, 06238 Villefranche-sur-mer, France \\ ${ }^{2}$ CNRS, UMR 7093, LOV, 06230 Villefranche-sur-Mer, France \\ *now at: Marine Physical Laboratory, Scripps Institution of Oceanography, University of California at San Diego, 95000 \\ Gilman Drive, La Jolla, CA 92093-0238, USA
}

Received: 29 August 2007 - Published in Biogeosciences Discuss.: 2 October 2007

Revised: 17 January 2008 - Accepted: 25 January 2008 - Published: 12 March 2008

\begin{abstract}
In the frame of the BIOSOPE cruise in 2004, the spatial distribution and structure of phytoplankton pigments was investigated along a transect crossing the ultraoligotrophic South Pacific Subtropical Gyre (SPSG) between the Marquesas Archipelago $\left(141^{\circ} \mathrm{W}-8^{\circ} \mathrm{S}\right)$ and the Chilean upwelling $\left(73^{\circ} \mathrm{W}-34^{\circ} \mathrm{S}\right)$. A High Performance Liquid Chromatography (HPLC) method was improved in order to be able to accurately quantify pigments over such a large range of trophic levels, and especially from strongly oligotrophic conditions. Seven diagnostic pigments were associated to three phytoplankton size classes (pico-, nano and microphytoplankton). The total chlorophyll- $a$ concentrations [TChl $a$ ] in surface waters were the lowest measured in the centre of the gyre, reaching $0.017 \mathrm{mg} \mathrm{m}^{-3}$. Pigment concentrations at the Deep Chlorophyll Maximum (DCM) were generally 10 fold the surface values. Results were compared to predictions from a global parameterisation based on remotely sensed surface [TChla]. The agreement between the in situ and predicted data for such contrasting phytoplankton assemblages was generally good: throughout the oligotrophic gyre system, picophytoplankton (prochlorophytes and cyanophytes) and nanophytoplankton were the dominant classes. Relative bacteriochlorophyll- $a$ concentrations varied around $2 \%$. The transition zone between the Marquesas and the SPSG was also well predicted by the model. However, some regional characteristics have been observed where measured and modelled data differ. Amongst these features is the extreme depth of the DCM $(180 \mathrm{~m})$ towards the centre of the gyre, the presence of a deep nanoflagellate population beneath the DCM or the presence of a prochlorophyte-enriched
\end{abstract}

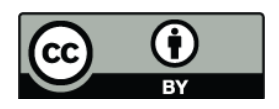

Correspondence to: J. Ras

(josephine.ras@obs-vlfr.fr) population in the formation area of the high salinity South Pacific Tropical Water. A coastal site sampled in the eutrophic upwelling zone, characterised by recently upwelled water, was significantly and unusually enriched in picoeucaryotes, in contrast with an offshore upwelling site where a more typical senescent diatom population prevailed.

\section{Introduction}

East of Tahiti, the South East Pacific Ocean is characterised by very contrasting trophic environments, covering a large range of total chlorophyll- $a$ concentrations [TChl $a$ ]. These environments comprise the "permanently" (Dandonneau et al., 2004) "hyper-oligotrophic" centre of the South Pacific Subtropical Gyre (SPSG; Longhurst, 1998; Claustre and Maritorena, 2003) where SeaWifs imagery presents average surface TChl $a$ concentrations of $0.02 \mathrm{mg} \mathrm{m}^{-3}$ (http: //oceancolor.gsfc.nasa.gov/SeaWiFS/). This gyre is distinguished by its hydrodynamic stability, its unique magnitude, the transparency of its waters (Morel et al., 2007) and extremely weak sources of nutrients from deeper layers (Raimbault et al., 2007) as well as from the atmospheric flux (Mahowald, 2005; Wagener et al., 2008; Claustre et al., 2008). To the West, the mesotrophic environment of the Marquesas archipelago prevails in a predominantly $\mathrm{HNLC}$ (High $\mathrm{Nu}-$ trient Low Chlorophyll) zone (Claustre et al., 2008 and references therein). To the East, the waters become strongly eutrophic as the Chilean coastline is subjected to an offshore transport of surface waters, thus inducing strong hydrodynamics and the upwelling of deep, cold and nutrient-rich waters at the coast (Longhurst, 1998; Claustre et al., 2008 and references therein).

Published by Copernicus Publications on behalf of the European Geosciences Union. 


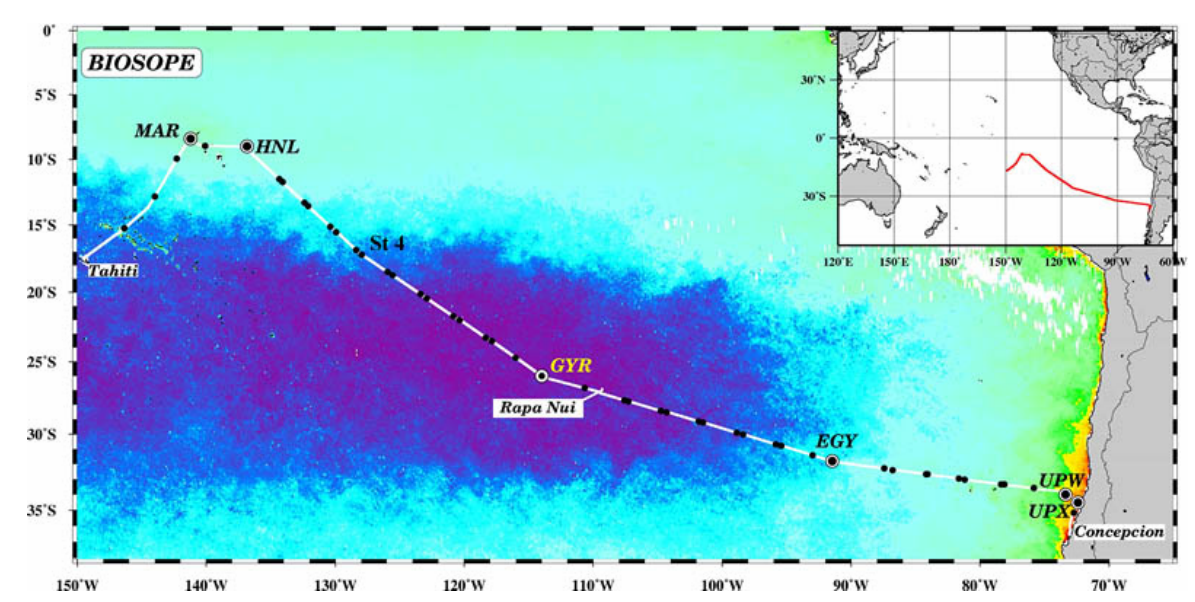

Fig. 1. Map of the BIOSOPE cruise track superimposed on a SeaWiFS ocean colour composite, the dark purple indicating the extremely low concentrations $\left(0.017 \mathrm{mg} \mathrm{m}^{-3}\right)$ of TChla.

The BIOSOPE cruise (BIOgeochemistry and Optics South Pacific Experiment), carried out from October to December 2004, took place between Tahiti (French Polynesia) and Concepcion (Chile). It can be described as a voyage of exploration across unique and contrasting environments where oceanographic data are still scarce to this day (Claustre and Maritorena, 2003). Besides the aspects of oceanographic investigation aiming at the assessment of the biogeochemical and optical properties of the ocean as a function of surface water [TChla] the wide range of trophic conditions observed during this cruise was ideal for carrying out calibration and validation activities for ocean colour remote sensors.

During the past decades, high performance liquid chromatography (HPLC) techniques have rapidly evolved, allowing for phytoplankton biomass and composition in the oceans to be described in detail using algal pigment biomarkers. Indeed, the $[\mathrm{TChl} a]$ has been a widely used biomarker for the phytoplankton biomass in the oceans (Yentch and Menzel, 1963; Parsons and Strickland, 1963; O'Reilly et al., 1998). Accessory pigments have either photosynthetic properties allowing the phytoplankton cells to increase their lightharvesting spectrum, or a role of photoprotection in dissipating the excess of light energy received and reducing the oxidation that takes place due to stress in conditions of strong irradiance. The major accessory pigments have also proven to be useful chemotaxonomic indicators (Goericke and Repeta, 1992; Wright and Jeffrey, 1987; Moore et al., 1995; Guillard et al., 1985). Hence, the chlorophyll- $a$ and accessory pigment distributions have become important descriptors of the spatial and temporal variations of the autotrophic biomass and taxonomic composition. From the pigment composition of natural communities, Claustre (1994), Vidussi et al. (2001), and recently Uitz et al. (2006), have proposed to derive pigment-based size classes relevant to picophytoplankton (less than $2 \mu \mathrm{m}$ ), nanophytoplankton (between 2 and $20 \mu \mathrm{m}$ ) and microphytoplankton (greater than $20 \mu \mathrm{m}$ ). Based on the statistical analysis of a global HPLC database, the proposed parameterisation allows these three pigmentbased size classes and their vertical distribution to be retrieved from remotely sensed TChla concentrations (Uitz et al., 2006). Although the database was extensive ( 2400 profiles), extremely few profiles were from the South East Pacific so that the "global" parameterisation might be somewhat biased not taking into consideration certain characteristics of this rather unknown and vast area.

Thus, in the context of the BIOSOPE cruise, the objectives related to the analysis of the distribution of phytoplankton pigments are double. The first aim of this study is essentially descriptive and explorative where the spatial (along transect and vertical) distribution of phytoplankton pigments is analysed in this "mare incognita" of the South-East Pacific Ocean. The second aim is to investigate whether the in situ distributions of pigment-based size classes conform with the predicted distributions derived from the application of the Uitz model to the remotely sensed (SeaWiFS) TChl $a$ concentrations. By doing so, it is expected that any difference between measured and predicted distributions could be scrutinized and further interpreted in terms of distinct regional features of the South-East Pacific relative to the mean (global ocean) trend.

\section{Material and methods}

\subsection{Sampling area}

Sampling was performed between the 26 October and the 11 December 2004 in the South Pacific along a transect starting in the vicinity of the Marquesas archipelago $\left(141^{\circ} \mathrm{W}, 8^{\circ} \mathrm{S}\right)$ and ending in the upwelling of the Chilean coast $\left(73^{\circ} \mathrm{W}\right.$, $35^{\circ} \mathrm{S}$ ) (Fig. 1). Six sites along this transect were studied 
over 2- to 5-day periods: MAR: Marquesas archipelago $\left(141.3^{\circ} \mathrm{W} ; 8.4^{\circ} \mathrm{S}\right)$; HNL: HNLC area east of the Marquesas islands $\left(136.8^{\circ} \mathrm{W} ; 9^{\circ} \mathrm{S}\right)$; GYR: centre of the South Pacific gyre (about 300 nautical miles west of the "navel of the world", a native name for Easter Island; $114^{\circ} \mathrm{W}, 26^{\circ} \mathrm{S}$ ); EGY: eastern border of the gyre $\left(91.4^{\circ} \mathrm{W}, 31.8^{\circ} \mathrm{S}\right)$; UPW: upwelling site situated above the abyssal plain, about 70 nautical miles from the coast $\left(73.3^{\circ} \mathrm{E} ; 34^{\circ} \mathrm{S}\right)$; UPX: upwelling site situated above the continental shelf, about 18 nautical miles from the coast $\left(72.4^{\circ} \mathrm{E}, 34.5^{\circ} \mathrm{S}\right)$. In addition, twenty one short-term (less than $5 \mathrm{~h}$ ) stations were studied each day during the transit between the long stations.

\subsection{Sample collection and storage}

Seawater samples were collected using a CTD-rosette system equipped with 21 twelve litre Niskin bottles. The samples for pigment analysis were collected at about 10 depths, twice a day, from the 09:00 a.m. and noon CTD casts (local time).

The water samples were vacuum filtered through $25 \mathrm{~mm}$ diameter Whatman GF/F glass fibre filters $(0.7 \mu \mathrm{m}$ particle retention size). Filtered volumes varied between $5.6 \mathrm{~L}$ in the hyper-oligotrophic waters and $1 \mathrm{~L}$ in the upwelling zone. The filters were immediately stored in liquid nitrogen then at $80^{\circ} \mathrm{C}$ until analysis on land.

2.3 Chlorophyll and carotenoid pigment extraction and analysis

Extraction and analysis of the BIOSOPE samples were completed between the 7 March and the 27 April 2005. The filters were extracted at $-20^{\circ} \mathrm{C}$ in $3 \mathrm{~mL}$ methanol $(100 \%)$, disrupted by sonication and clarified one hour later by vacuum filtration through Whatman GF/F filters. The extracts were rapidly analysed (within $24 \mathrm{~h}$ ) by HPLC with a complete $A g$ ilent Technologies system (comprising LC Chemstation software, a degasser, a binary pump, a refrigerated autosampler, a column thermostat and a diode array detector)

The pigments were separated and quantified following an adaptation of the method described by Van Heukelem and Thomas (2001). Modifications to this method allowed for increased sensitivity in the analysis of ultra-oligotrophic waters. As an example of the sensitivity and resolution of the method, Figs. 2a and b represent two typical chromatograms originating from the centre of the gyre (surface and Deep Chlorophyll Maximum respectively) where at least sixteen pigment peaks were identified.

The sample extracts (100\% methanol), premixed (1:1) with a buffer solution (tetrabutylammonium acetate or TBAA $28 \mathrm{mM}$ ), were injected onto a narrow reversed-phase C8 Zorbax Eclipse XDB column $(3 \times 150 \mathrm{~mm} ; 3.5 \mu \mathrm{m}$ particle size) which was maintained at $60^{\circ} \mathrm{C}$. Separation was achieved within 28 min with a gradient between a solution (A) of TBAA $28 \mathrm{mM}$ : methanol (30:70; v:v) and a solution (B) of $100 \%$ methanol according to the following program:
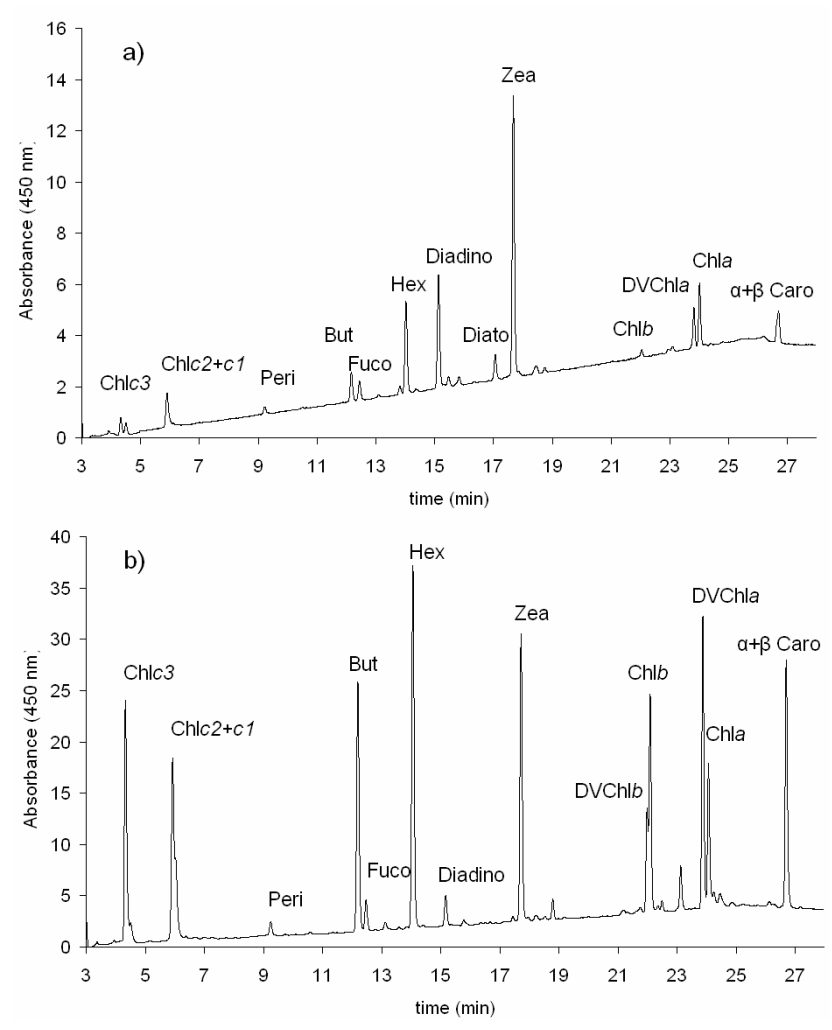

Fig. 2. HPLC chromatograms from (a) the surface and (b) the DCM at $180 \mathrm{~m}$ at the hyper-oligotrophic GYR station. Detection absorption wavelength is $450 \mathrm{~nm}$.

(t(min);\%B;\%A), (0;10;90), (25;95;5), (28;95;5). A diode array detector allowed for the absorption of most pigments to be detected at $450 \mathrm{~nm}$, while chlorophyll- $a$ and its derivatives were detected at $667 \mathrm{~nm}$ and bacteriochlorophyll- $a$ at $770 \mathrm{~nm}$. The diode array absorption spectra of each peak were used for identification purposes.

Pigment concentrations (in $\mathrm{mg} \mathrm{m}^{-3}$ ) were calculated from the peak areas with an internal standard correction (Vitamin E acetate, Sigma) and external calibration standards which were provided by DHI Water and Environment (Denmark).

This method has proven to be satisfactory in terms of resolution, sensitivity, accuracy and precision (Hooker et al., 2005), with the detection of about 25 separate phytoplankton pigments (listed in Table 1), with a lower limit of detection (3 times Signal:Noise ratio) for chlorophyll- $a$ of $0.0001 \mathrm{mg} \mathrm{m}^{-3}$ and with an injection precision of $0.4 \%$.

\subsection{Phytoplankton pigment-based size classes}

While TChl $a$ is the universal proxy for phytoplankton organisms, accessory pigments (chlorophylls- $b$ and $c$, and carotenoïds) are specific to phytoplankton groups (Table 1), and their respective proportion to TChla is a proxy of the community composition (e.g. Gieskes et al., 1988; Jeffrey and Vesk, 1997; Mackey et al., 1996; Prézelin et al., 2000). 
Table 1. List of the pigments used in this study, along with their abbreviations, calculation and their taxonomic significance (From Jeffrey and Vesk, 1997). The main algal groups used here to describe the phytoplankton community composition are indicated in bold.

\begin{tabular}{|c|c|c|c|}
\hline Chlorophylls & Abbreviation & Sum & $\begin{array}{l}\text { Taxonomic or biogeochemical } \\
\text { significance }\end{array}$ \\
\hline Chlorophyll- $a$ & Chla & Chl $a+$ allomers + epimers & All - except Prochlorophytes \\
\hline Divinyl Chlorophyll- $a$ & DVChla & & Prochlorophytes \\
\hline Total Chlorophyll- $a$ & TChla & Chl $a+$ DVChl $a+$ Chld a & All \\
\hline Chlorophyll- $b$ & Chlb & & Green algae \\
\hline Divinyl Chlorophyll- $b$ & DVChlb & & Prochlorophytes \\
\hline Total Chlorophyll- $b$ & TChlb & Chlb + DVChlb & Green algae, Prochlorophytes \\
\hline Chlorophyll-c2 & Chlc2 & & Various \\
\hline Chlorophyll-c3 & Chlc3 & & Prymnesiophytes, Chrysophytes \\
\hline Bacteriochlorophyll- $a$ & BChla & & Photoheterotrophic bacteria \\
\hline Peridinin & Peri & & Dinoflagellates \\
\hline 19'-Butanoyloxyfucoxanthin & But & & Pelagophytes, prymnesiophytes \\
\hline Fucoxanthin & Fuco & & $\begin{array}{l}\text { Diatoms, prymnesiophytes, } \\
\text { some Dinoflagellates }\end{array}$ \\
\hline 19'-Hexanoyloxyfucoxanthin & Hex & & Prymnesiophytes \\
\hline Zeaxanthin & Zea & & Cyanobacteria, Prochlorophytes \\
\hline Alloxanthin & Allo & & Cryptophytes \\
\hline Diatoxanthin & Diato & & Various \\
\hline Diadinoxanthin & Diadino & & Various \\
\hline Lutein & Lut & & Chlorophytes \\
\hline Neoxanthin & Neo & & Green algae \\
\hline Violaxanthin & Viola & & Green algae \\
\hline Prasinoxanthin & Pras & & Prasinophytes \\
\hline Carotenes & Car & $\mathrm{a}-\mathrm{Car}+\mathrm{b}-\mathrm{Car}$ & Various \\
\hline Chlorophyllide- $a$ & Chld $a$ & Chld $a+$ Chld $a$-like & Senescent diatoms \\
\hline Phaeophorbide $a$ & Phd $a$ & Phd $a+$ Phd $a$-like & Grazor faecal pellets \\
\hline Phaeophytin $a$ & Phtna & & Grazor faecal pellets \\
\hline
\end{tabular}

Here we used the pigment grouping method proposed by Claustre (1994) and Vidussi et al. (2001) and recently improved by Uitz et al. (2006). Seven pigments are used as biomarkers of several phytoplankton taxa: fucoxanthin, peridinin, alloxanthin, 19'-butanoyloxyfucoxanthin, $19^{\prime}$-hexanoyloxyfucoxanthin, zeaxanthin, total chlorophyll- $b$ (for abbreviations see Table 1). These taxa are then gathered into three size classes (micro-, nano-, and picophytoplankton), according to the average size of the cells. The fraction of each pigment-based size class with respect to the total phytoplankton biomass is calculated as follows:

Greater than $20 \mu \mathrm{m}: f_{\text {micro }}=(1.41[$ Fuco $]+1.41[$ Peri $]) / \mathrm{wDP}$

2 to $20 \mu \mathrm{m}: f_{\text {nano }}=(0.60[$ Allo $]+0.35[\mathrm{But}]+1.27[\mathrm{Hex}]) / \mathrm{wDP}$

Less than $2 \mu \mathrm{m}: f_{\text {pico }}=(0.86[$ Zea $]+1.01[\mathrm{TChlb}]) / \mathrm{wDP}$

where wDP is the sum of the concentration of the seven weighted diagnostic pigments:

$$
\begin{aligned}
\mathrm{wDP}= & 1.41[\text { Fuco }]+1.41[\text { Peri }]+0.60[\text { Allo }]+0.35[\text { But }] \\
& +1.27[\mathrm{Hex}]+0.86[\text { Zea }]+1.01[\text { TChlb }]
\end{aligned}
$$

Each diagnostic pigment is associated to a coefficient which represents an estimate of the average ratio of the TChl $a$ concentration to the diagnostic pigment concentration. These coefficients have been obtained by multiple regression analysis, performed on a global pigment database (Uitz et al., 2006). Eventually the TChla biomass associated with each class is derived according to:

$$
\begin{aligned}
& {[\text { TChl } a]_{\text {micro }}=\mathrm{f}_{\text {micro }} \times[\text { TChl } a]} \\
& {[\text { TChl } a]_{\text {nano }}=f_{\text {nano }} \times[\text { TChl } a]} \\
& {[\text { TChl } a]_{\text {pico }}=f_{\text {pico }} \times[\text { TChl } a]}
\end{aligned}
$$

\subsection{Computation of the in situ derived euphotic depth}

The depth of the euphotic zone (Ze), representing the depth where irradiance is reduced to $1 \%$ of its surface value, was computed using the in situ [TChl $a$ ] profiles according to the model developed by Morel and Maritorena (2001). The water column [TChl $a$ ] was progressively integrated with increasing depths and Ze was consequently determined through an iterative process which is described in Morel and Berthon (1989).

2.6 Remotely sensed surface chlorophyll- $a$ used to derive the phytoplankton vertical community composition

The algorithm developed by Uitz et al. (2006) was applied, and the vertical profiles of [TChla] associated with the three 


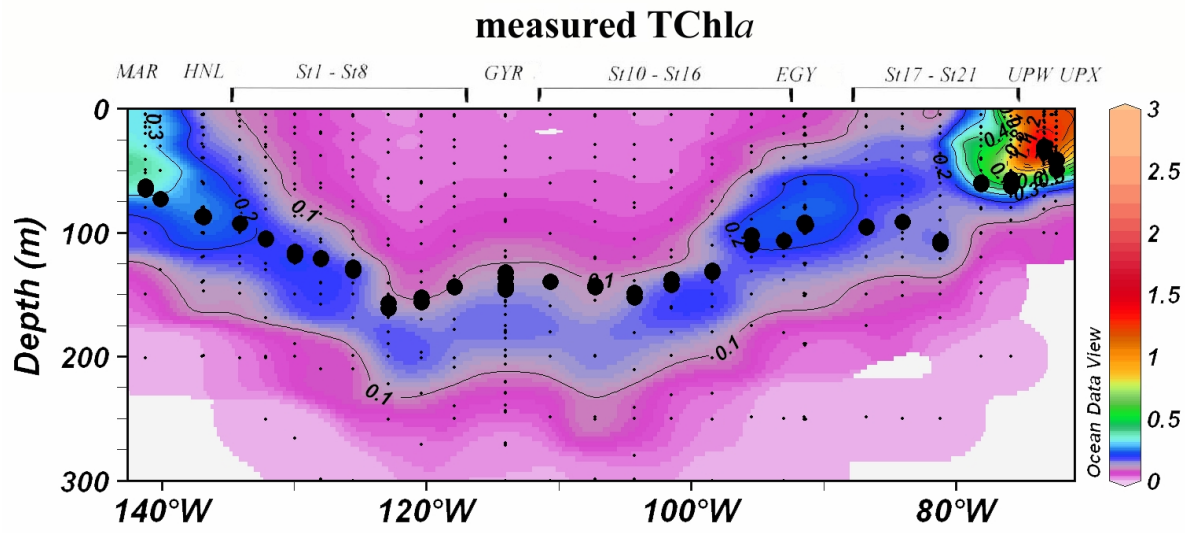

Fig. 3. Contour plot of the measured TChl $a$ concentrations $\left(\mathrm{mg} \mathrm{m}^{-3}\right)$ for the Biosope cruise transect. Large black dots represent the depth of the euphotic layer, Ze (m). Small black dots represent collected water samples at each sampling station. (Ocean Data View (ODV) software, version 3.0.1, R. Schlitzer, http://odv.awi-bremerhaven.de/, 2005).

afore-mentioned pigment-based size classes were derived. This implies the use of the near-surface TChla concentrations, which can be obtained from remotely sensed ocean colour.

For each station sampled during the BIOSOPE cruise, the corresponding near-surface [TChla] was extracted from SeaWiFS imagery ([TChl $a]_{\mathrm{sat}}, \mathrm{mg} \mathrm{m}^{-3}$ ), given the geographic location and date of sampling. When no $[\mathrm{TChl} a]_{\text {sat }}$ was available, values were extracted from the SeaWiFS images corresponding to \pm 1 day, \pm 2 days, or \pm 3 days, with respect to the date of in situ sampling. For 39\% of the stations, the date of SeaWiFS and in situ measurements coincided, for $42 \%$ they were 1-day shifted, for $10 \%$ they were 2-day shifted, and for $9 \%$ they were 3-day shifted. This strategy was chosen in order to keep all the data. A detail of the full procedure to derive vertical profiles is given in Uitz et al. (2006). Only a short summary is given below.

Firstly, the satellite derived euphotic depth was computed from the $[\mathrm{TChl} a]_{\text {sat }}$ value by using successively the statistical relationship linking [TChl $a]_{\text {sat }}$ and the column-integrated content (Eq. 8 of Uitz et al., 2006), and that of Morel et Maritorena (2001) relating the column-integrated content and $Z e_{\text {sat }}$. The euphotic depth was then compared to the mixed layer depth $(\mathrm{Zm})$ to determine whether the water column was stratified (i.e. $\mathrm{Ze} \geq \mathrm{Zm}$ ) or mixed (i.e. $\mathrm{Ze}<\mathrm{Zm}$ ). For stratified waters, the $[\mathrm{TChl} a]_{\text {sat }}$ value was used to generate dimensionless profiles (with respect to depth and to biomass) of TChl $a$ associated with micro-, nano-, and picophytoplankton. Depth profiles were restored to physical units by multiplying the depths by $Z e_{\text {sat }}$ and the concentrations by the mean TChla concentration within the euphotic layer. For mixed waters, the $[\mathrm{TChl} a]_{\text {sat }}$ value was used to determine the proportion of each pigment-based size class, eventually multiplied by the $[\mathrm{TChl} a]_{\text {sat }}$ value, and extended through the water column to generate uniform vertical profiles.

\section{Results}

\subsection{General hydrographic conditions}

General hydrographic conditions, including the distribution of temperature and salinity, are detailed in the introduction of this special issue (Claustre et al., 2008).

\subsection{Pigment distribution}

In terms of algal biomass (Fig. 3), the surface TChl $a$ concentrations were lowest at the hyper-oligotrophic centre of the SPSG ( $0.017 \mathrm{mg} \mathrm{m}^{-3}$ at station 6), while the highest surface values were found at both ends of the transect in the eutrophic upwelling area (up to $1.5 \mathrm{mg} \mathrm{m}^{-3}$ ) and in the mesotrophic Marquesas area $\left(0.200\right.$ to $\left.0.400 \mathrm{mg} \mathrm{m}^{-3}\right)$. Furthermore, a progressive deepening of the DCM towards the centre of the gyre could be observed, varying from $50 \mathrm{~m}$ depth in the Marquesas area to $180 \mathrm{~m}$ in the centre of the gyre (reaching $190 \mathrm{~m}$ at Station 6). Pigment concentrations at the DCM in the SPSG were generally 10 fold those observed at the surface (Fig. 4a). Down to $50 \mathrm{~m}$ at the Chilean upwelling, the TChl $a$ profile is generally homogenous.

The mean clear sky daily PAR irradiance at the surface is 51.8 mol quanta $\mathrm{m}^{-2} \mathrm{~d}^{-1}$ (Huot et al., 2007). This covers the whole transect, the variability due to latitude being insignificant. Figure 3 illustrates how the $\mathrm{Ze}$, which therefore corresponds to the $0.5 \mathrm{~mol}$ quanta $\mathrm{m}^{-2} \mathrm{~d}^{-1}$ isolume, closely follows the position of the DCM except in the centre of the gyre where the DCM is clearly below the Ze.

In contrast with TChla, the accessory pigments do not all exhibit the same East-West "symmetrical" distribution. Figure 5 illustrates the vertical distribution of 6 representative pigments.

Total chlorophyll- $b$ or TChl- $b$ (Fig. 5a), reflecting both chlorophytes, prasinophytes (chlorophyll- $b$ ) and prochlorophytes (divinyl chlorophyll- $b$ ), showed minimum 

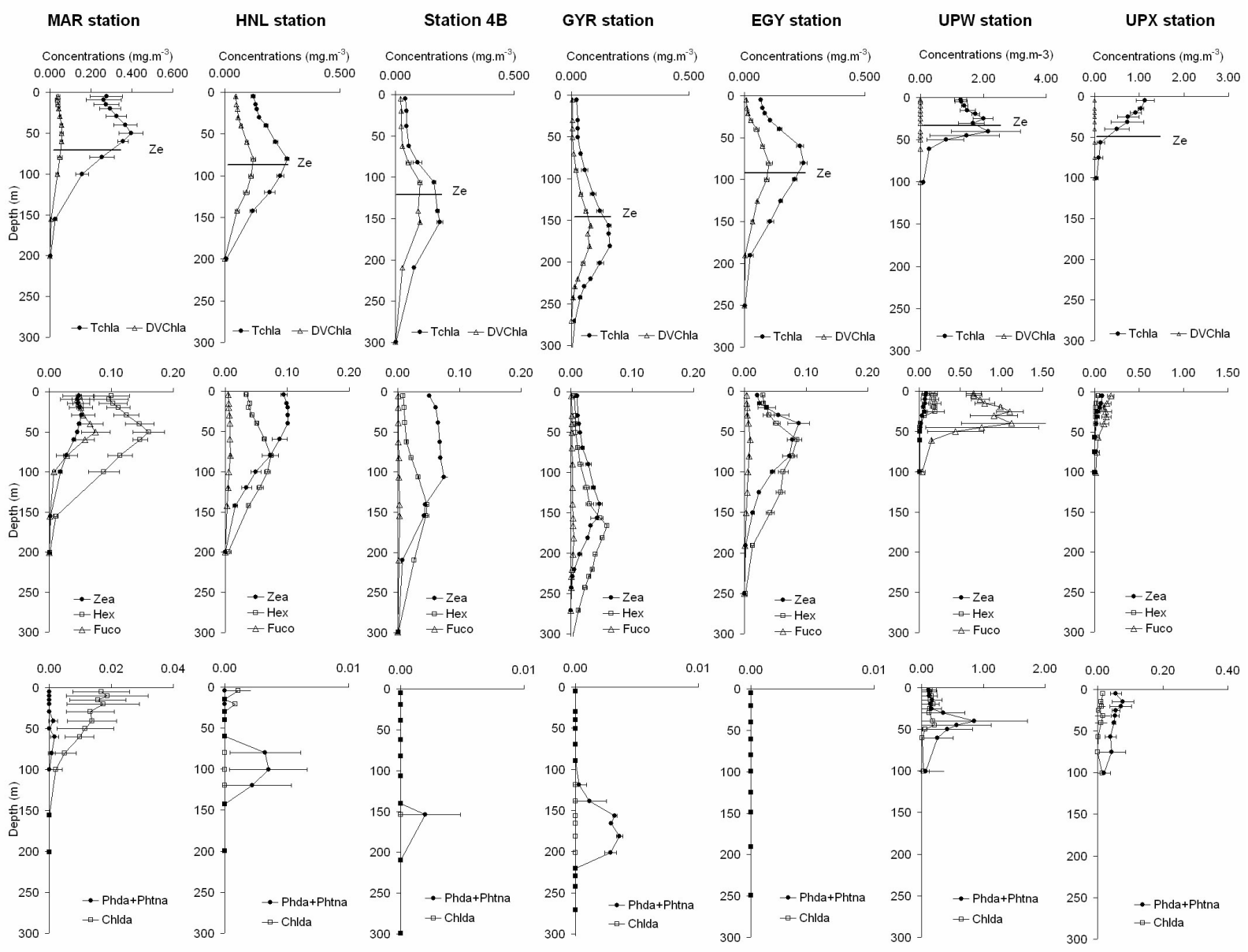

Fig. 4. Average vertical pigment profiles $\left(\mathrm{mg} \mathrm{m}^{-3}\right)$ at the MAR, HNL, St4B, GYR, EGY, UPW and UPX sites: (a) Total chlorophyll- $a$ and divinyl chlorophyll- $a$, the horizontal lines represent the depth of the euphotic layer (Ze); (b) zeaxanthin, 19'-hexanoyloxyfucoxanthin and fucoxanthin; (c) degradation products: phaeophorbide $a+$ phaeophytin $a$ and chlorophyllide- $a$. Horizontal bars represent the average value \pm SD.

concentrations at the surface of the gyre (less than $0.001 \mathrm{mg} \mathrm{m}^{-3}$ ), while the deep maximum (down to $200 \mathrm{~m}$ ) could reach more than $0.100 \mathrm{mg} \mathrm{m}^{-3}$. Maximum concentrations were encountered at station $20\left(0.245 \mathrm{mg} \mathrm{m}^{-3}\right)$ and station UPX $\left(0.400 \mathrm{mg} \mathrm{m}^{-3}\right)$. Because divinyl chlorophyll $b$ is totally absent in the upwelling zone, this feature is likely the signature of green eukaryotes. A remarkable feature in the gyre system is the high TChl- $b$ concentration below the DCM which is essentially composed of divinyl chlorophyll- $b$ (reaching up to $100 \%$ of TChlb).

Divinyl chlorophyll- $a$ or DVChl- $a$, (Figs. $4 \mathrm{a}$ and 5b), representative of prochlorophytes, was detected over the whole studied area, except for the upwelling zone, with surface water concentrations varying around $0.040 \mathrm{mg} \mathrm{m}^{-3}$ at the MAR station, increasing to 0.050 at the HNL station then progressively decreasing to $0.003 \mathrm{mg} \mathrm{m}^{-3}$ in the centre of the gyre. East of the gyre, surface concentrations did not exceed $0.008 \mathrm{mg} \mathrm{m}^{-3}$. At depth, the distribution of DVChl $a$ concentrations generally followed that of the DCM (Fig. 4a).
The photoprotecting zeaxanthin or Zea (Figs. 4b and $5 \mathrm{c}$ ), found in cyanobacteria and prochlorophytes, showed very low surface values in the centre of the gyre (around $0.010 \mathrm{mg} \mathrm{m}^{-3}$ at the surface) and progressively increasing concentrations with depth, with a maximum (about $0.050 \mathrm{mg} \mathrm{m}^{-3}$ ) above the DCM, around $150 \mathrm{~m}$. A particular zone, coinciding with the South Pacific Tropical Water mass between HNL and station 4, was characterised by high and constant zeaxanthin concentrations between the surface and $100 \mathrm{~m}$ depth. In the upwelling area, zeaxanthin was detected in very low concentrations, while the photoprotecting diadinoxanthin and diatoxanthin, (essentially typical pigments of diatoms and prymnesiophytes) significantly increased (data not shown).

19'-Hexanoyloxyfucoxanthin or Hex (Figs. 4b and 5d), representative of chromophyte nanoflagellates, was detected throughout the whole studied area, with highest concentrations at the extremities of the transect: in the Marquesas archipelago $\left(0.060-0.130 \mathrm{mg} \mathrm{m}^{-3}\right.$ and $0.130-0.180 \mathrm{mg} \mathrm{m}^{-3}$ 

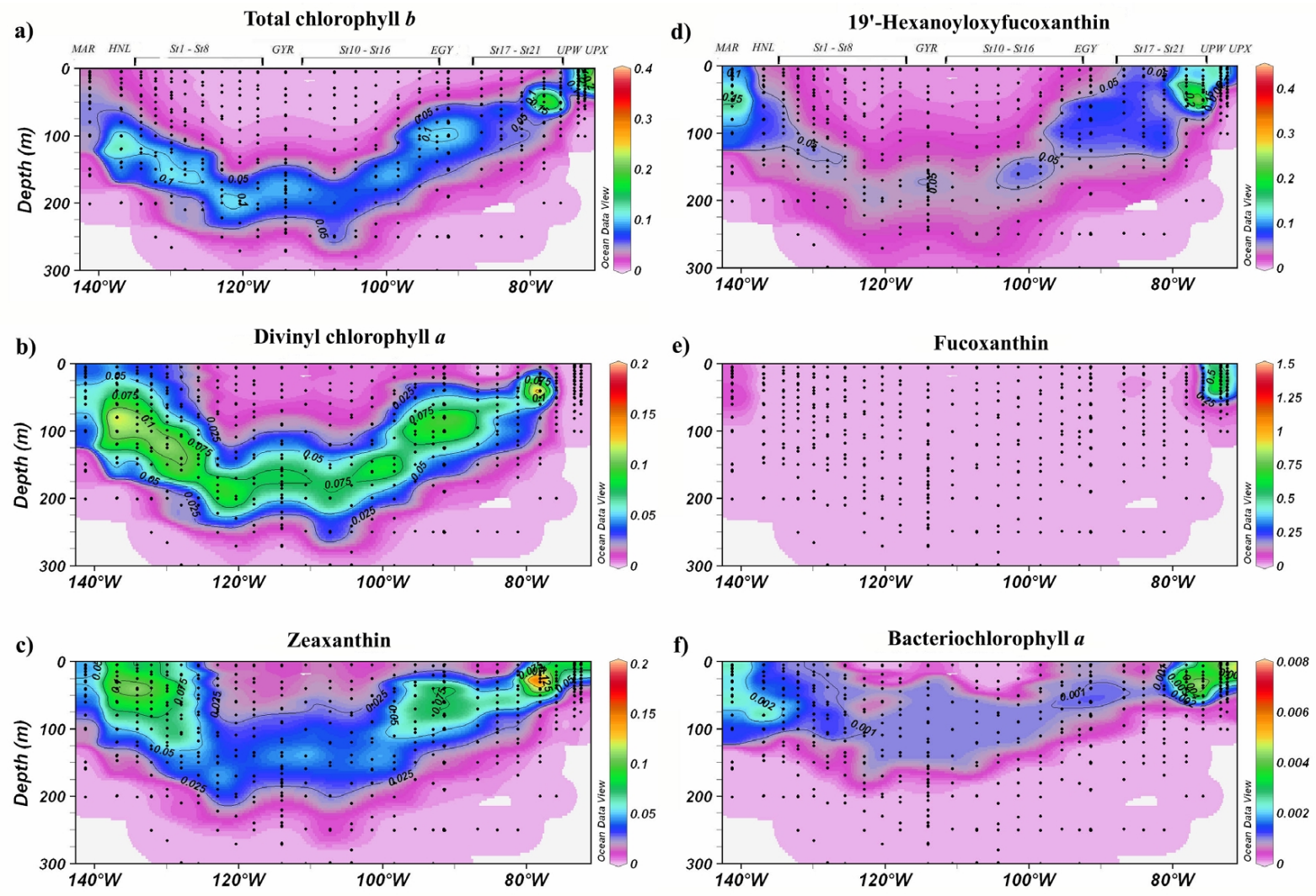

Fig. 5. Vertical cross sections for pigment concentrations $\left(\mathrm{mg} \mathrm{m}^{-3}\right)$ across the BIOSOPE cruise transect. (a) Total chlorophyll- $b$; (b) divinyl chlorophyll- $a$; (c) zeaxanthin; (d) 19'-hexanoyloxyfucoxanthin; (e) fucoxanthin; (f) bacteriochlorophyll- $a$.

at the surface and $50 \mathrm{~m}$ depth respectively), around stations 20 and $21\left(0.140 \mathrm{mg} \mathrm{m}^{-3}\right.$ and $0.400 \mathrm{mg} \mathrm{m}^{-3}$ at the surface and $50 \mathrm{~m}$ depth respectively) and at station UPW (0.140$0.230 \mathrm{mg} \mathrm{m}^{-3}$ and $0.320 \mathrm{mg} \mathrm{m}^{-3}$ at the surface and $40 \mathrm{~m}$ depth respectively). The $19^{\prime}$-hexanoyloxyfucoxanthin concentrations at the UPX site were lower than $0.067 \mathrm{mg} \mathrm{m}^{-3}$. Lowest concentrations were found at the centre of the gyre: $0.005 \mathrm{mg} \mathrm{m}^{-3}$ at the surface and $0.050 \mathrm{mg} \mathrm{m}^{-3}$ at the DCM. Interestingly, throughout the central gyre the Hex concentrations were twice higher around $270 \mathrm{~m}$ depth than at the surface $\left(0.011 \mathrm{mg} \mathrm{m}^{-3}\right)$.

Fucoxanthin or Fuco (Figs. $4 \mathrm{~b}$ and $5 \mathrm{e}$ ), a tracer of diatoms, was found in very low amounts throughout the SPSG. Significant concentrations were only found in the Marquesas waters $\left(0.020\right.$ to $0.080 \mathrm{mg} \mathrm{m}^{-3}$ at the surface and up to $0.100 \mathrm{mg} \mathrm{m}^{-3}$ at $50 \mathrm{~m} \mathrm{depth}$ ) and in the upwelling zone, particularly at station UPW $\left(0.700\right.$ and $1.600 \mathrm{mg} \mathrm{m}^{-3}$ at the surface and at $40 \mathrm{~m}$ depth respectively). Fucoxanthin concentrations did not exceed $0.200 \mathrm{mg} \mathrm{m}^{-3}$ at station UPX.

At the MAR station, bacteriochlorophyll- $a$ concentrations (BChl- $a$, Fig. 5f) in the first $100 \mathrm{~m}$ varied around 0.0015 and $0.0035 \mathrm{mg} \mathrm{m}^{-3}$. At the HNL station, they were variable but lower than at MAR (between 0.0010 and $0.0016 \mathrm{mg} \mathrm{m}^{-3}$ ), although a slight deep maximum was observed around $80 \mathrm{~m}$ depth $\left(0.0015\right.$ to $\left.0.0033 \mathrm{mg} \mathrm{m}^{-3}\right)$. The surface BChla concentrations within the gyre system remained extremely low and close to detection limits $\left(0.0005 \mathrm{mg} \mathrm{m}^{-3}\right)$, while a BChla deep maximum was observed around $100 \mathrm{~m}$ $\left(0.0010 \mathrm{mg} \mathrm{m}^{-3}\right)$. In the upwelling area, the BChla concentrations were the highest measured over the whole transect (between 0.0020 and $0.0090 \mathrm{mg} \mathrm{m}^{-3}$ ).

Minor pigments such as prasinoxanthin and alloxanthin, respectively associated to prasinophytes and cryptophytes, were never detected in the Marquesas area and hardly in the SPSG (data not shown). However, prasinoxanthin, associated to chlorophyll- $b$, as well as neoxanthin, violaxanthin and lutein (typical indicators of chlorophytes and prasinophytes), were found in significant concentrations at the coastal upwelling UPX site, thus suggesting an important localised contribution of green picophytoplankton in these waters.

Chlorophyllide- $a$ or Chlid $a$ and phaeopigments (Fig. 4c) were scarce in the gyre, sometimes detectable at the DCM. Chlid $a$ was present in significant and variable amounts at the MAR and UPW stations. The degradation products derived from the demetallation of chlorophyll- $a$ associated to grazing activities (phaeophorbide- $a$ and phaeophytin- $a$ ) were found in high concentrations essentially in the upwelling area, with 

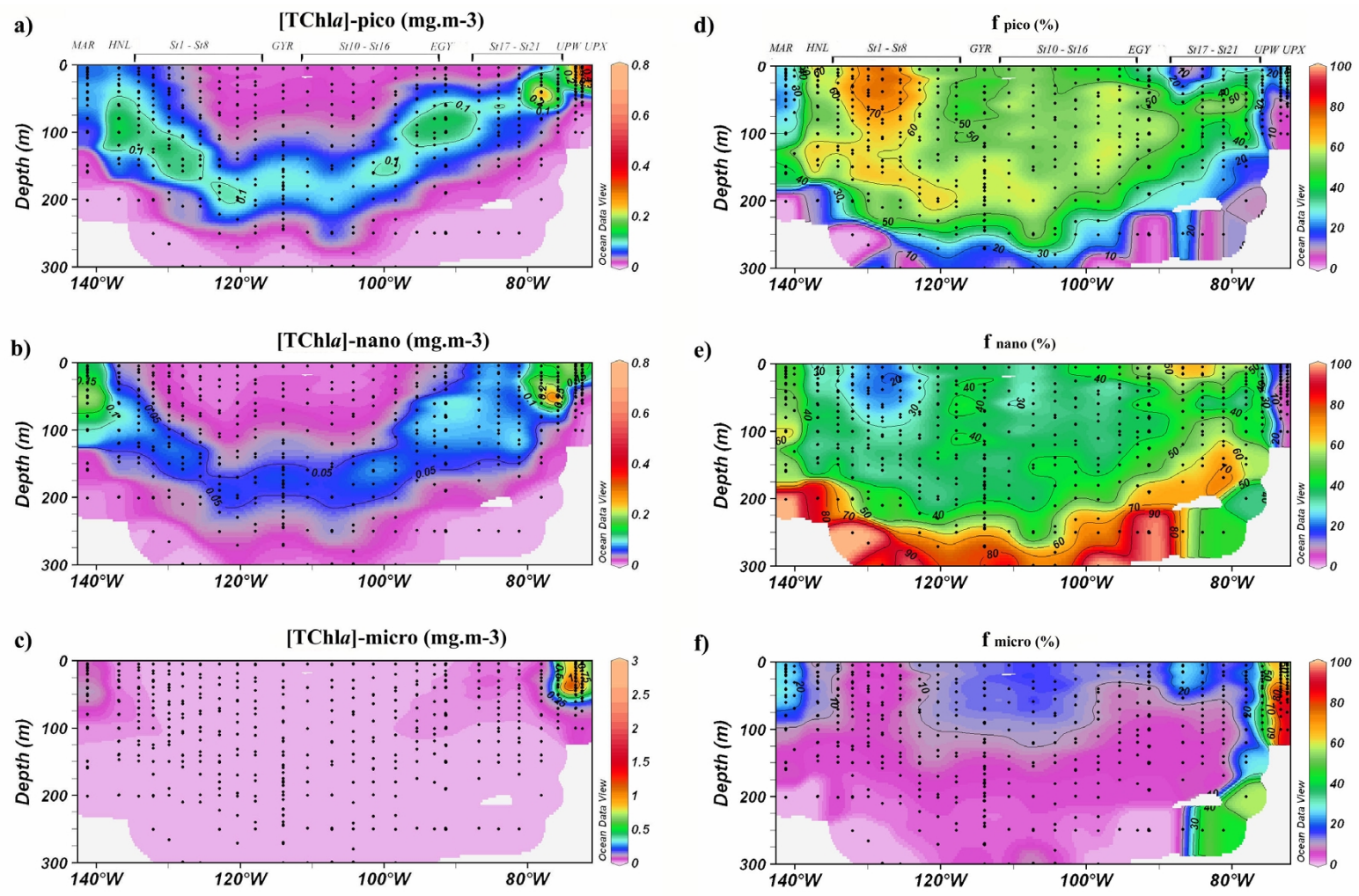

Fig. 6. Biosope cruise cross sections of in situ TChla concentrations in $\mathrm{mg} \mathrm{m}^{-3}$ (a-c) and percentages (e-g) associated to the pico-, nanoand microphytoplankton size classes. Black dots represent sampling points.

the phaeopigment to TChl $a$ ratio increasing constantly with depth up to values of 1.500. Degradation pigment concentrations generally showed a good correlation with the fucoxanthin concentrations (data not shown).

\subsection{Distribution of the phytoplankton pigment based size classes}

Picophytoplankton, represented by cyanobacteria and prochlorophytes in this study, present similar variations to TChla (Fig. 6a), with a deep maximum coinciding with the DCM (around $180 \mathrm{~m}$ in the centre of the gyre). Picophytoplankton is unusually high at the UPX station. In terms of percentages of TChla, the highest values for picophytoplankton $(>70 \%)$ are found associated with South Pacific Tropical Water (SPTW) between stations 2 and 5 (Fig. 6d). Elsewhere in the gyre, the proportion of picophytoplankton varies between 40 and $60 \%$ down to $250 \mathrm{~m}$. Nanophytoplankton in the gyre system varies in concentrations and proportions that are comparable to the picophytoplankton (Figs. $6 \mathrm{~b}$ and 6e), although below $250 \mathrm{~m}$, it is found in proportions greater than $60 \%$ (essentially due to the quasi dominance of Hex). At the MAR station, nanophytoplankton is the predominant class. Surface waters at stations 17 and 18 also present relatively high proportions of nanophytoplakton $(>60 \%)$, while minimal proportions are found in the SPTW area $(<30 \%)$ and in the upwelling zone. Microphytoplankton, as for fucoxanthin, points to the scarcity in diatom populations across the gyre system (Fig. 6c). Interestingly, a slight increase in the proportion of essentially fuco-containing phytoplankton is observed in the surface waters of the central gyre $(>10 \%$, Fig. 6f) while proportions are less than $10 \%$ in the rest of the gyre system. The Marquesas waters are also enriched in fucoxanthin-containing microphytoplankton ( $>20 \%)$. In the upwelling zone, microphytoplankton represents more than $60 \%$ of the TChla biomass. The contribution of peridinin to the microphytoplankton pool is generally low, but there are some exceptions: for example the Peri to Fuco ratio is particularly high $(>2)$ in the SPTW area and at sites 15 and 20.

3.4 TChl $a$ biomass and pigment-based size classes: modelled versus in situ data

\subsubsection{Global trends in Tchla}

The vertical sections of the TChla concentrations obtained from in situ measurements and from the model are presented in Figs. 3 and 7, respectively. The comparison between these 


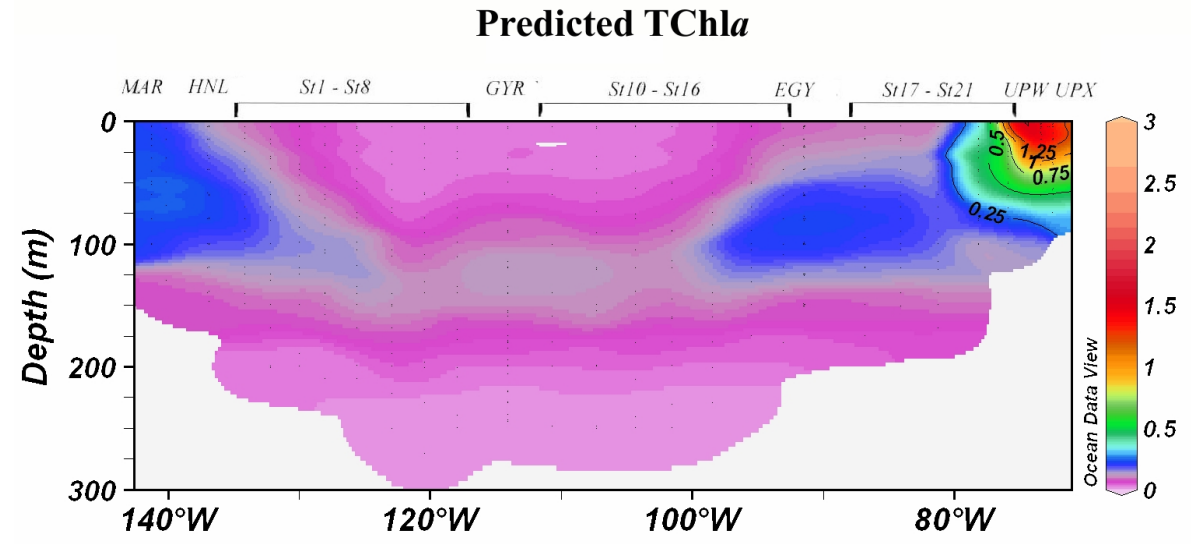

Fig. 7. Contour plot of the predicted TChl $a$ concentrations $\left(\mathrm{mg} \mathrm{m}^{-3}\right)$ for the BIOSOPE cruise transect. (Ocean Data View (ODV) software, version 3.0.1, R. Schlitzer, http://odv.awi-bremerhaven.de/, 2005).

In situ data from the BIOSOPE cruise
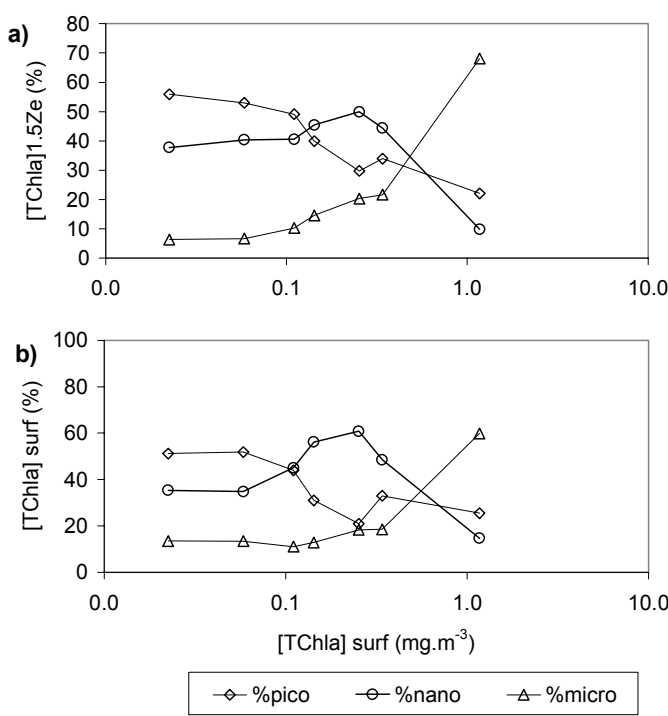

Predicted data for the BIOSOPE cruise
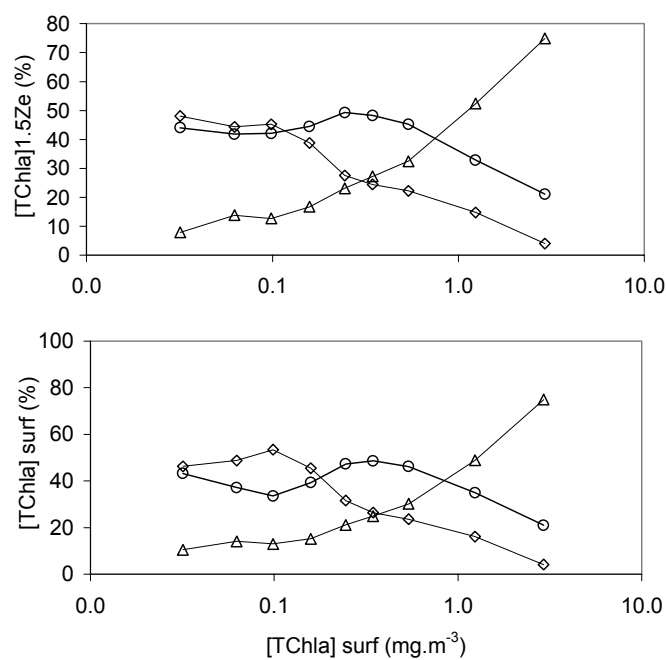

Fig. 8. Composition of the phytoplankton population as a function of surface TChla concentrations for in situ and model data. (a) integrated percentages of pico-, nano- and microphytoplankton between 0 and $1.5 \mathrm{Ze}$ and (b) surface percentages of pico-, nano- and microphytoplankton.

two figures illustrates the capacity of the model to reproduce the general trends in the horizontal and vertical distribution of the TChla. Notably, the model simulates the gradient observed in the surface concentrations with extremely low values in the core of the gyre $\left(\approx 0.030 \mathrm{mg} \mathrm{m}^{-3}\right)$ and higher values at the extremities of the transect, i.e. in the vicinity of the Marquesas Islands and of the upwelling of Chile $\left(\approx 1.500 \mathrm{mg} \mathrm{m}^{-3}\right)$. It also reproduces the surface maximum at each end of the transect as well as the deepening of the maximum in the centre of the gyre. Besides these similarities however, the depth of the TChla maximum is significantly underestimated in the core of the gyre $(\approx 120 \mathrm{~m}$ according to the model vs. $180 \mathrm{~m}$ following in situ measurements).

\subsubsection{Global trends in pigment-based size classes}

In a first approach we considered the contribution of the three pigment-based size classes to the total phytoplankton biomass as a function of the surface [TChla]. To do so, the same procedure as described in Uitz et al. (2006) was used. Namely, the average contribution of each phytoplankton size class was calculated for the surface layer on the one hand, and for the $0-1.5 \mathrm{Ze}$ layer on the other hand, for nine trophic categories defined by successive intervals of surface [TChla]. The resulting contributions are compared to those obtained from the global dataset from which the model has been derived (Fig. 6 in Uitz et al., 2006). The changes 
a)

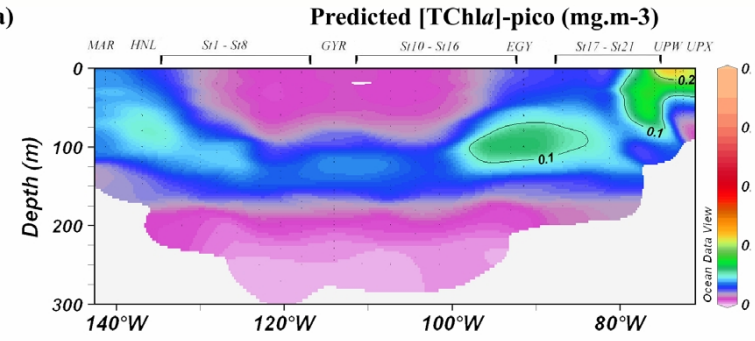

b)

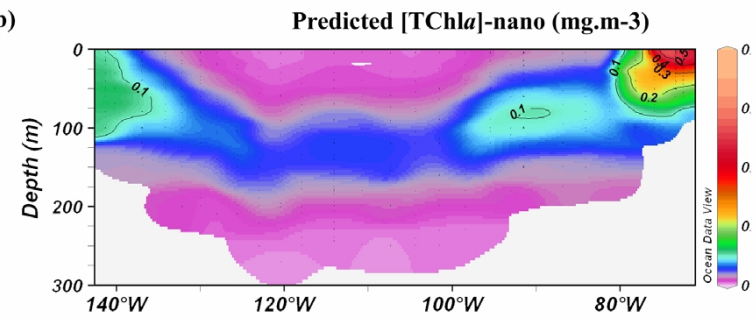

c)

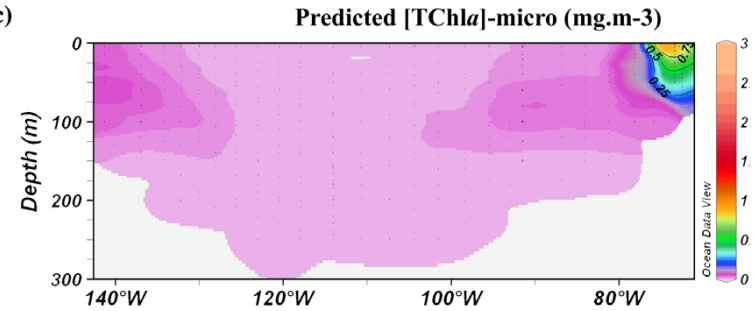

d)

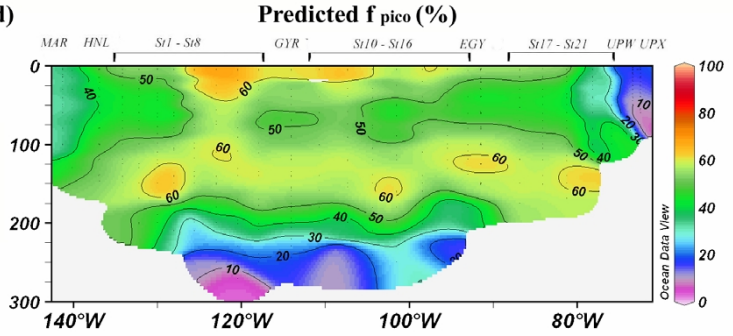

e)

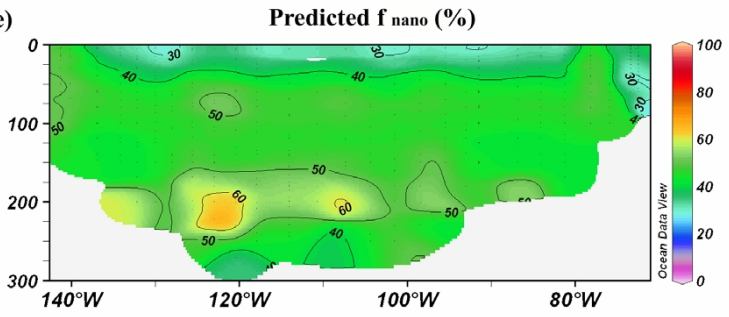

f)

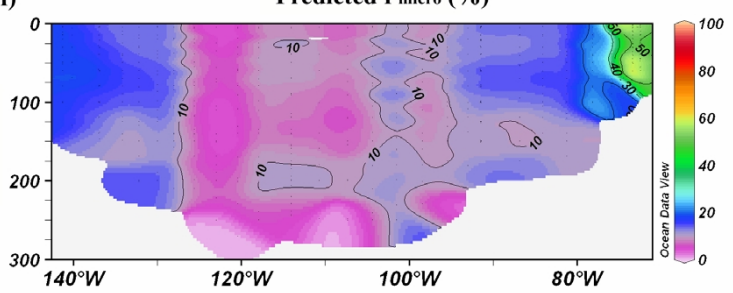

Fig. 9. Cross sections of the predicted TChl $a$ concentrations along the BIOSOPE transect for pico-, nano- and microphytoplankton, expressed in $\mathrm{mg} \mathrm{m}^{-3}$ (a-c) and percentages $(\mathbf{d}-\mathbf{f})$.

in the contribution of the three pigment-based size classes as a function of the surface [TChla] display the same general trend for both datasets (Fig. 8). Indeed, the contribution of microphytoplankton tends to increase with the surface TChl $a$ concentration, and reaches up to $50-60 \%$ for a surface [TChla] of $1.000 \mathrm{mg} \mathrm{m}^{-3}$. In contrast, picophytoplankton dominate in oligotrophic conditions $(\approx 50 \%$ for a surface [TChla] of $0.030 \mathrm{mg} \mathrm{m}^{-3}$ ) and nanophytoplankton in mesotrophic conditions $(\approx 50 \%$ for a surface [TChl $a$ ] of $0.500 \mathrm{mg} \mathrm{m}^{-3}$ ).

\subsubsection{Deviations with respect to the global trends}

The comparison between in situ data and predictions shows that, at a first order, the model performs well for the wide range of trophic situations encountered along the BIOSOPE transect (Fig. 8). The sections of the absolute and relative TChla concentrations of micro-, nano- and picophytoplankton obtained from the model are presented in Fig. 9, to be compared to Fig. 6 (in situ data). In terms of absolute concentrations, the model displays similar values to those measured in situ. The global trends are also well represented in terms of relative values, as expected from Fig. 8. This exercise thus represents an a posteriori validation of the model considering that the BIOSOPE dataset was not included in the database from which the model has been derived. In addition, this comparison exercise allows the identification of several features where the phytoplankton composition is not typical of the model-based composition associated to a given surface [TChla]. These particularities may be related to the very unique spatial and temporal features (large- or smallscale) that occurred within the study region. Within the following discussion, several areas, characterized by atypical pigment distributions and associations, will be depicted.

\section{Discussion}

\subsection{General trends}

\subsubsection{Dominance of picophytoplankton in the South Pacific Subtropical Gyre}

Between stations 1 and 16 (from $13.5^{\circ} \mathrm{S} ; 132.1^{\circ} \mathrm{W}$ to $31.4^{\circ} \mathrm{S} ; 93^{\circ} \mathrm{W}$ ), picophytoplankton is generally the most abundant size class $(50-60 \%$ of the phytoplankton biomass down to $250 \mathrm{~m}$ ). This observation is consistent with other studies in tropical and subtropical areas of the world ocean (Claustre and Marty, 1995; Bidigare and Ondrusek, 1996; Mackey et al., 1996; Dandonneau et al., 2006). In these 
strongly illuminated waters, cyanobacteria essentially dominate the phytoplankton populations. Synechococcus are more abundant at the surface and Prochlorococcus at depth (Fig. 11b and Fig. 11c). When DVChla concentrations from the BIOSOPE cruise were compared with data from the Atlantic subtropical gyre systems (Uitz et al., 2006), it resulted that such low surface concentrations had never yet been measured and that, as for TChla, the deep maximum concentration was significantly deeper than observed elsewhere (data not shown). The effect of photoacclimation (Falkowski and LaRoche, 1991; Partensky et al., 1996; Claustre and Marty, 1995) may explain this observation. It can also lead to an eventual increase of the accessory pigments to TChla ratios with depth (MacIntyre et al., 2002). However this is not a rule, since the pigments do not all react similarly with changing irradiance. Prochlorophytes are known to reach maximal relative abundances in highly stratified and extremely nutrient-depleted waters (Partensky et al., 1999; Johnson and Howd, 2000). Either variations in community structure or photoadaptive processes within the cells (phenotypic versus genotypic modifications), may explain the observed vertical structure of the prochlorophyte population with divinyl chlorophyll- $a$ prevailing in the upper $180 \mathrm{~m}$ (DCM included) while a layer of divinyl chlorophyll- $b$-rich water sits at the base of the DCM (DVChl$b /$ DVChl- $a<0.1$ above $150 \mathrm{~m}$ and $\approx 2$ at $300 \mathrm{~m}$ depth, see also Fig. 11a). Goericke and Repeta (1993) and Partensky et al. (1996) made similar observations in the North Atlantic. Moore and Chisholm (1999), Partensky et al. (1999), Johnson et al. (2006), Bouman et al. (2006) and Garczarek et al. (2006) support the hypothesis that several genetically different prochlorophyte populations coexist over a vertical light gradient. These ecotypes would be characterised by varying DVChl $b$ to DVChla ratios indicating their adaptation to low-light (below the thermocline) or high-light (in the upper mixed layer) environments. The extent of the depth reached by prochlorophyte populations may not only depend on light and on nutrients, but may also be limited by temperature. Indeed, in the SPSG, the divinyl chlorophyll- $a$ and divinyl chlorophyll- $b$ concentrations were always detected above the $11^{\circ} \mathrm{C}$ isotherm, as has been previously observed by Dandonneau et al. (2006) and Partensky et al. (1999).

\subsubsection{Ubiquity of nanophytoplankton in the South Pacific}

Throughout most of the SPSG, nanophytoplankton, essentially represented by Hex, corresponded to $40-50 \%$ of the TChla biomass down to $200 \mathrm{~m}$ depth (Fig. 11d). The ubiquity of the nanophytoplankton class, even in conditions of hyper-oligotrophy and high irradiance, reflects a strong capacity for adapting to the extreme conditions encountered along the transect and as well as at great depths where nutrients become available. Caution must be taken with the definition of nanophytoplankton as it is essentially based on the presence of Hex and But. In the study area, especially at
Table 2. Average values \pm SD of the $0-1.5 \mathrm{Ze}$ integrated TChla contents $\left(\mathrm{mg} \mathrm{m}^{-2}\right)$ associated to the total phytoplankton biomass and to the three pigment-based size classes: pico-, nano- and microphytoplankton between stations 1 and 16 for the gyre system and for stations MAR, EGY, UPW and UPX.

\begin{tabular}{ccccc}
\hline Stations & TChl $a$ & {$[$ TChl $a]$-pico } & {$[$ TChl $a]$-nano } & {$[$ TChl $a]$-micro } \\
\hline St1-St16 & $20.3 \pm 2.1$ & $11.6 \pm 1.7$ & $7.4 \pm 0.8$ & $1.3 \pm 0.3$ \\
MAR & $30.2 \pm 2.8$ & $7.1 \pm 0.1$ & $15.7 \pm 1.6$ & $7.4 \pm 1.4$ \\
EGY & $23.0 \pm 0.5$ & $11.6 \pm 0.5$ & $9.7 \pm 0.4$ & $1.7 \pm 0.1$ \\
UPW & $79.2 \pm 22.7$ & $3.8 \pm 1.6$ & $8.7 \pm 3.4$ & $66.7 \pm 18.3$ \\
UPX & $37.4 \pm 6.9$ & $17.8 \pm 2.1$ & $3.0 \pm 0.2$ & $16.5 \pm 4.5$ \\
\hline
\end{tabular}

the surface, these pigments which are typical for flagellates could however belong to smaller cells which may be part of the picophytoplankton pool. Further information would be needed to assess the real definition of size classes relative to the pigment composition in such oligotrophic waters.

\subsubsection{Importance of photoheterotrophic bacteria in olig- otrophic waters}

BChla-containing photosynthetic bacteria were most representative in the centre of the SPSG, with average surface BChla/TChl $a$ ratios of $2 \%$ progressively decreasing down to $0 \%$ at $170 \mathrm{~m}$ depth (Fig. 11f). These values are much lower than the range of 5 to $10 \%$ mentioned by Kolber et al. (2001). The results from the BIOSOPE cruise agree better with Cottrell et al. (2006) who measured ratios between $0.3 \%$ and $2.6 \%$ in the Mid-Atlantic Bight and are higher than those measured by Goericke (2002) in the oligotrophic California Current System (0.7\%). This is consistent with parallel measurements done by Lami et al. (2007) who found high standing stocks of aerobic anoxygenic phototrophic (AAP) bacteria above the DCM in the SPSG.

\subsubsection{The Marquesas Archipelago - HNLC transition zone}

Comparison with the model data essentially focuses on the transition between the MAR and HNL sites, as the pigment distribution differs from one site to another. At the MAR site, the average integrated TChl $a$ biomass between the surface and $1.5 \mathrm{Ze}$ varied around $30.2 \pm 2.8 \mathrm{~g} \mathrm{~m}^{-2}$ (Table 2). Bidigare and Ondrusek (1996) measured values (between 0 and

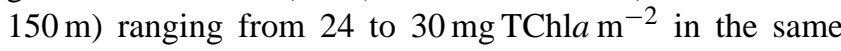
area. Nanophytoplankton was the predominant size class (50-60\%) between 0 and $175 \mathrm{~m}$ as equally predicted by the model. This is well represented by the Hex distribution. Above $80 \mathrm{~m}$ depth, the microphytoplankton pool had similar proportions to picophytoplankton (20-25\% each), while below $80 \mathrm{~m}$ it decreased to less than $10 \%$ (Figs. $6 \mathrm{~d}$ and $\mathrm{f}$ ). The MAR site was also the only site of the transect (apart from the upwelling), where signs of diatom senescence could be found. Microscopic observations showed significant counts 


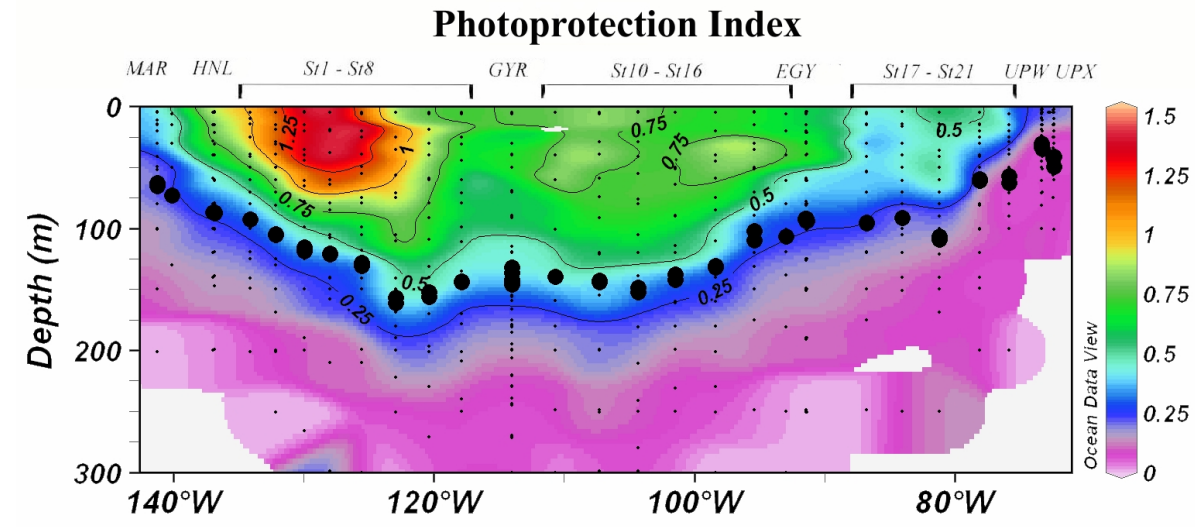

Fig. 10. Contour plot of the Photoprotection Index (PI) across the BIOSOPE transect. The large black dots represent the depth of the euphotic layer (Ze). The small black dots represent the collected water samples at each station. (Ocean Data View (ODV) software, version 3.0.1, R. Schlitzer, http://odv.awi-bremerhaven.de/, 2005).

of diatoms and a low number of dinoflagellate populations (Gomez, personal communication, 2006). The proportion of peridinin also remained low, confirming the weak contribution of the dinoflagellate population. This is in agreement with previous observations in the Equatorial Pacific Ocean (Bidigare and Ondrusek, 1996). However precautions may need to be taken with the interpretation of the peridinin concentrations, as dinoflagellates that do not contain peridinin, like certain Gymnodinium sp., have already been observed in these waters (Chavez et al., 1990; Landry et al., 2000).

As expected, the HNL site, being "upstream" of the South Equatorial Current, was more typical of the stratified oligotrophic gyre waters, with a two fold increase in the proportion of picophytoplankton (Fig. 6d). A strong proportion of picophytoplankton, essentially prochlorophytes, prevailed around $130 \mathrm{~m}$. An unusually high contribution of DVChl $b$ was also observed at this depth. Nanophytoplankton represented about $30 \%$ of the total TChl $a$ biomass (Fig. 6e). The proportion of microphytoplankton showed a discrete maximum around $60 \mathrm{~m}$ but remained below $12 \%$ (Fig. 6f), with a higher contribution of peridinin (dinoflagellates). It appears that the algal population at the HNL site is influenced by the proximity of the more hydrodynamically stable South Pacific Tropical Water formation area rather than the turbulent waters of the Marquesas Islands (Signorini et al., 1999).

4.2 Geographical particularities in the pigment distribution and associations

\subsubsection{Extreme depth of the DCM in the Central South Pa- cific subtropical gyre}

The chlorophyll maximum has rarely been observed to reach such remarkable depths in the global ocean as those encountered here. Although comprehensive, the dataset on which the model is based does not include data collected in such extreme oligotrophic conditions as those encountered during the BIOSOPE cruise. Unsurprisingly, this made it difficult to predict the extent of the chlorophyll maximum in the centre of the gyre. Although some small nuances exist in the pigment distribution, the main and more important particularity of the SPG remains its exceptional transparency (Morel et al., 2007). This is likely the result of exceptional weak diffusive nutrient fluxes from the deep nutricline. Throughout the gyre, the integrated TChl $a$ concentrations between 0 and $1.5 \mathrm{Ze}$ varied around $20.3 \pm 2.1 \mathrm{mg} \mathrm{m}^{-2}$ (Table 2) and fall within the range of those measured between 0 and $250 \mathrm{~m}$ by Claustre and Marty (1995) in the North Tropical Atlantic Ocean. This implies that although the phytoplankton biomass can develop at larger depths than in other parts of the world ocean, the biomass integrated down to $1.5 \mathrm{Ze}$ seemingly remains comparable to other subtropical gyre systems. The phytoplankton community therefore follows the same general trends as observed for other gyres with the noticeable difference that the distribution is more extended (diluted) over the geometric depth. Actually with respect to euphotic depth (the ratio Z/Ze) the DCM in the SPG is located deeper than in other gyres. The DCM is generally associated to the depth of the euphotic zone in other subtropical gyres (Letelier et al., 2004; Uitz et al., 2006), while for the most oligotrophic stations of the SPG, it was located at $\sim 1.2 \mathrm{Ze}$ (i.e. at $190 \mathrm{~m}$ for $\mathrm{Ze}=160 \mathrm{~m}$ ). Consequently, phytoplankton at the level of the DCM and below has developed the most extreme adaptation characteristics with respect to light.

The adaptation to these extreme optical conditions can also be investigated through light intensity, characterised by the photoprotection index PI:

$$
\mathrm{PI}=(\text { Diadinoxanthin }+ \text { Diatoxanthin }+ \text { Zeaxanthin }) /[\text { TChla }],
$$

As expected, the values of the PI increase towards the surface, but more interestingly, the depths of the euphotic layer along the cruise track appear to closely follow the vertical variations in the PI (Fig. 10). 

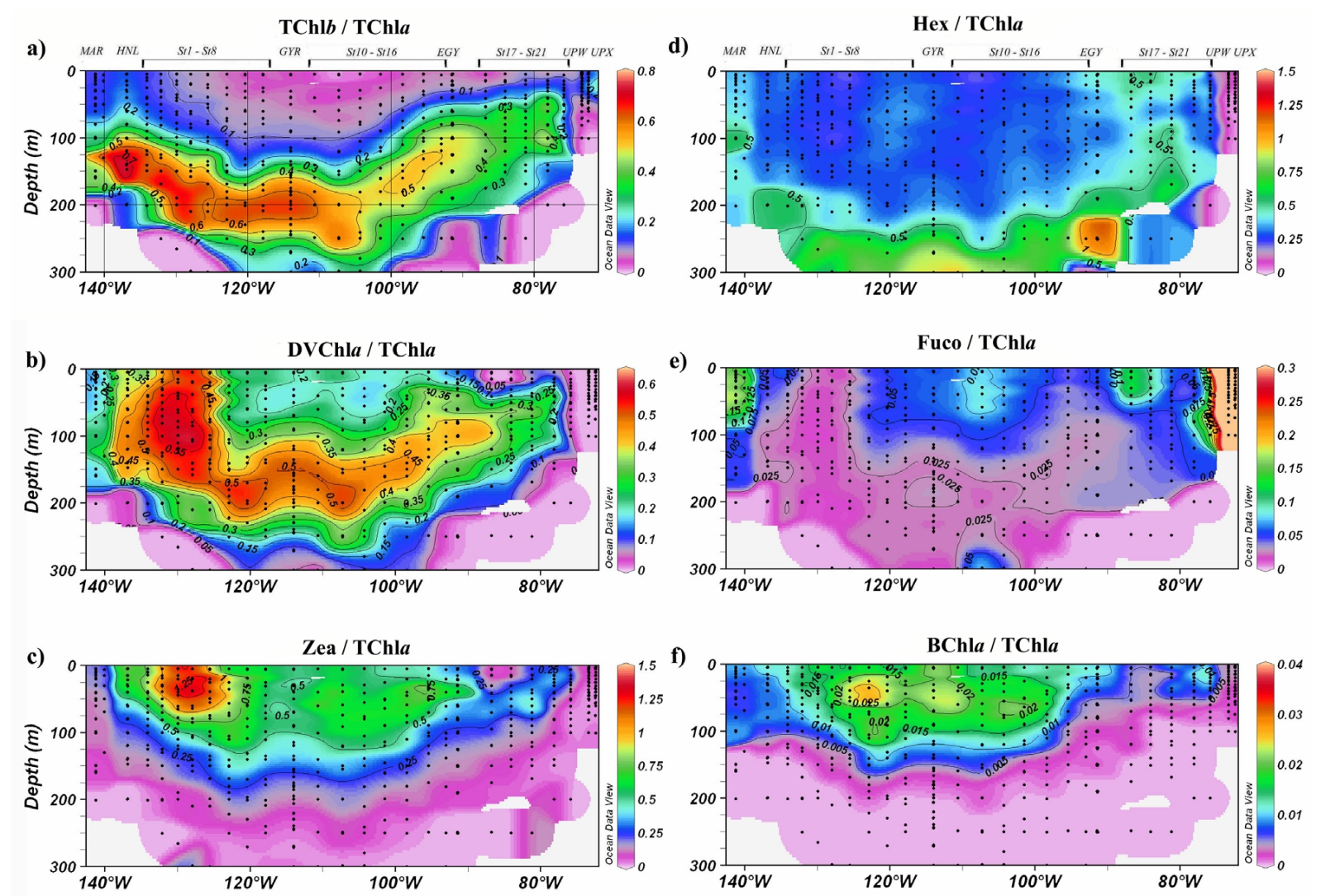

Fig. 11. Cross sections for pigment concentrations normalised to Total chlorophyll- $a$ across the BIOSOPE cruise transect. Total chlorophyll-b/TChl-a; (b) Divinyl Chlorophyll-a/TChl- $a$; (c) Zeaxanthin/TChl $a$; (d) 19'-Hexanoyloxyfucoxanthin/TChl $a$; Fucoxanthin/TChl $a$; (f) Bacteriochlorophyll- $a /$ TChl- $a$.

\subsubsection{A deep nanoflagellate population}

A sudden increase in the proportion of nanophytoplankton was observed at the base of the DCM (Fig. 11d). This feature has been observed in other subtropical gyre systems (Claustre and Marty, 1995; Monger et al., 1999), but the reasons for its existence are still unclear. Claustre and Marty (1995) suggest that this deep nanoflagellate population can develop close to the nutricline, which is the case here. Other types of measurements from the cruise indicated that this deep layer was particularly rich in coccoliths (Beaufort et al., 2007). Twardowski et al. (2007) observed a high backscattering ratio in this layer and suggest that this population may correspond to the coccolithophorid Florispharea profunda.

\subsubsection{Slight increase in microphytoplankton in the centre of the SPSG}

The microphytoplankton group was extremely sparse in the SPSG. Nevertheless, in the $0-80 \mathrm{~m}$ surface layer, a slight increase in the proportion of microphytoplankton, essentially represented by fucoxanthin (Fig. 11e), was observed at the centre of the gyre (particularly station 11). In contrast,
Gomez (2007), in accordance with the model results, describes a distinct decrease of the diatom population towards the centre of the gyre and towards the surface. Therefore according to microscopic observations this small increase of fucoxanthin should not originate from a diatom population (Gomez, personal communication), unless the diatom cells are smaller than $15 \mu \mathrm{m}$ (lower limit of detection for the microscopic method).

Certain endosymbiont cyanobacteria, attached to particular diatom genera, directly fix dinitrogen and can supply all the nitrogen required to their host (Carpenter, 2002). Venrick (1974) and Scharek et al. (1999) have reported that several diatom species of the genera Hemiaulus or Rhizosolenia in association with the diazotroph cyanobacteria Richelia intracellularis are able to survive in oligotrophic surface waters. Indeed, although in low abundance, Hemiaulus hauckii were observed by microscopy to be the only diatom species at the surface at station 12 (Gomez, personal communication, 2006). Nevertheless, very little is yet known about these symbioses. Other large species of diatoms (Ethmodiscus, Rhizosolenia mats) or dinoflagellates (Pyrocystis) can migrate between the nutricline and surface waters in 
nutrient-poor conditions (Villareal et al., 1999; Singler and Villareal, 2005), but apart from the presence of Nitzschia and Dactyliosolen between 200 and $300 \mathrm{~m}$ depth in the gyre, no significant microscopic observations are available. An alternative explanation may be the presence of other Fucocontaining phytoplankton groups, such as haptophytes or pelagophytes, but no other associated pigments behave like Fuco in this area, except for Peri which shows higher proportions in the surface waters of the SPSG. Hardy et al. (1996) and Gomez (personal communication, 2006) have observed small dinoflagellates to occur in the surface waters of the central gyre. Certain species of dinoflagellates are known to contain Fuco, especially when Peri is absent (Morden and Sherwood, 2002). So even though Fuco and Peri do not correlate well, one can hypothesise that the Fuco contribution in these waters may partly originate from dinoflagellate populations.

4.2.4 Very strong signature of prochlorophytes in the South Tropical Surface Water

The North-western border of the South Pacific Subtropical Gyre is under the influence of the South Equatorial Current (SEC) and represents typical HNLC (High Nutrient Low Chlorophyll) conditions. Between stations 2 and 5, the reasons for the particularly high proportion of picophytoplankton (Fig. 6d), and more precisely Prochlorococcus, down to $150 \mathrm{~m}$, seem unclear. Their development is nevertheless associated to the remarkably high-salinity waters (36.5) of the South Tropical Surface Water (STSW), where a stronger evaporation rate relative to precipitation occurs (Johnson and McPhaden, 1999) and surface nutrient levels remain, as in the rest of the gyre system, below detection limits (Raimbault, 2007). This water mass can be characterised by a very specific prochlorophyte-dominated picophytoplanktonic population. A a consequence, the Zea/TChl $a$ ratios are also exceptionally high (greater than 1) above $65 \mathrm{~m}$ depth (Fig. 11c). It is also the only part of the transect where the relative Fuco concentration represents less than $2.5 \%$ of the TChla biomass (Fig. 11e). As the surface TChla biomass in this zone is not exceptional in comparison to the rest of the gyre, the model does not predict such an unusual distribution in the phytoplankton population. The prevailing conditions and the exceptional phytoplankton population in this area would definately deserve further investigation.

4.2.5 High variability in community structure in the upwelling area

Only the upwelling region was characterised by a proportion of microphytoplankton above $30 \%$ (Fig. 6f). This was also reflected by the model data (Fig. 9f). However both sites seem to have been very different in a taxonomical point of view, a difference which could not be predicted by the model. Table 2 summarizes, for the 0 to $1.5 \mathrm{Ze}$ layer, the differences observed between these 2 sites, with a higher and more variable integrated TChl $a$ biomass at UPW than at UPX, the former being dominated by the microphytoplankton and the latter by equivalent proportions of pico- and microphytoplankton. The offshore UPW station was characteristic of a typically mature spring bloom with higher biomass concentrations essentially represented by diatoms which had probably been advected offshore from the upwelling zone. This is confirmed by the nutrient concentrations (Raimbault et al., 2007) that showed near-depletion in the surface waters of the UPW site and which may attribute the decrease of phytoplankton biomass towards the surface as a beginning of nutrient starvation. Furthermore, signs of pigment degradation related to senescence and grazing were highest for this site (Fig. 5c). Stuart et al. (2004) had similar results along the Chilean coast, i.e. typical upwelling features with high phytoplankton biomass (above $10 \mathrm{mg} \mathrm{m}^{-3}$ ) and microphytoplanktonpredominant populations, especially above the shelf break, and lower concentrations over the continental shelf and offshore regions. Only one site in their study presented unusually high relative concentrations of $\mathrm{Chl} b$ and Zea.

The surface waters of the coastal UPX site were dominated by a picoeukaryotic community ( 49 to $70 \%$ of picophytoplankton between the surface and $30 \mathrm{~m}$ depth), while it represented less than $10 \%$ of the TChla biomass at the diatom-dominated UPW site. The pigments associated to the picoeukaryotic chlorophytes, prasinophytes and cryptophytes were essentially found in the upwelling zone only, with absolute and relative concentrations several fold higher at the UPX site than at UPW. The flow cytometry data also indicated a maximum in concentrations of picoeukaryotes at this site (Grob, 2007). According to the temperature profiles, UPX was seemingly the site of recent upwelling of cold deep waters and the observed phytoplankton community was probably at an early stage of development. Experimental tests by Duarte et al. (2000a and b) on a Mediterranean community showed how increasing nutrient inputs lead to an initial autotrophic response of picophytoplankton (particularly Synechoccocus) which is later rapidly replaced by a stronger and more robust population of microphytoplankton. Furthermore, Larsen et al. (2004) and Bratbak et al. (1990) also witnessed an increase in autotrophic picoeukaryotes and/or cyanobacteria preceding a diatom spring bloom. Claustre et al. (1994) observed a similar event along a geostrophic front, where a ubiquitous flagellate biomass, associated to recently upwelled water, was observed to develop rapidly before being dominated by a slower developing diatom population. The picophytoplankton population at UPX was dominated by picoeukaryotes and not cyanobacteria (very low zeaxanthin concentrations) nor flagellates (the nanophytoplankton class varied at background levels at less than $10 \%$, values which are largely overestimated by the model), but the observations of Claustre et al. (1994), Duarte et al. (2000a, b) and Larson et al. (2004) could corroborate the idea that this young picophytoplankton community had quickly responded to a recent 
input of nutrients at the surface before being taken over by a diatom-dominated population. These transient communities are not usually observed in eutrophic zones as they probably occur at small time-scales. They are thus difficult to measure and even more to forecast with global models like the one used in this study.

\section{Conclusions}

As expected, the surface waters of the South Pacific Subtropical Gyre are the site of extremely low concentrations of phytoplankton biomass, requiring highly sensitive analytical techniques. The HPLC analytical method applied in this study was especially modified in order to adapt to such low concentrations and due to the low limits of detection obtained, an accurate and precise coverage of the different phytoplankton pigments with taxonomical significance has been achieved.

A phytoplankton pigment parameterisation, based on remotely sensed surface TChl $a$ concentrations was applied to the BIOSOPE transect and the predicted values were compared to the in situ data. In a first approach, the general patterns produced by the model were relatively well validated by the in situ data across such contrasting environments. However, in detail, this has revealed certain areas where the phytoplankton populations deviate from their typical composition that would be expected from the surface TChla concentrations. These are specific temporal or spatial features that cannot be depicted by a global parameterisation. The pigment signatures observed during the BIOSOPE cruise thus point to new issues and questions which could be the object of upcoming studies regarding the development of phytoplankton populations in the extreme conditions encountered in the ultra-oligotrophic center of the gyre, in the high salinity SPTW formation area or in eutrophic upwelling zones in general.

The outcome of such a comparison is a very promising new methodology for identifying atypical structures: indeed the model used here could be applied to data from other parts of the global ocean and could thus become a useful tool for rapidly pinpointing pigment associations and distributions that deserve special interest.
Acknowledgements. We thank the captain and crew of the $\mathrm{R} / \mathrm{V}$ Atalante for their pleasant cooperation during the BIOSOPE cruise. We also appreciate the time and effort provided by B. Gentili for computations. D. Tailliez and C. Marec are warmly thanked for their efficient help in CTD rosette management and data processing. This is a contribution of the BIOSOPE project of the LEFE-CYBER program. This research was funded by the Centre National de la Recherche Scientifique (CNRS), the Institut des Sciences de l'Univers (INSU), the Centre National d'Etudes Spatiales (CNES), the European Space Agency (ESA), The National Aeronautics and Space Administration (NASA) and the Natural Sciences and Engineering Research Council of Canada (NSERC).

Edited by: E. Boss

\section{References}

Beaufort, L., Couapela, M., Bucheta, N., and Claustre, H.: Calcite production by Coccolithophores in the South Pacific Ocean: from desert to jungle, Biogeosciences Discuss., 4, 3267-3299, 2007 , http://www.biogeosciences-discuss.net/4/3267/2007/.

Bidigare, R. R. and Ondrusek, M. E.: Spatial and temporal variability of phytoplankton pigment distributions in the central equatorial Pacific Ocean, Deep-Sea Res. II, 43(4-6), 809-833, 1996.

Bouman, H. A., Ulloa, O., Scanlan, D.J., Zwirglmaier, K., Li, W. K. W., Platt, T., Stuart, V., Barlow, R., Leth, O., Clementson, L., Lutz, V., Fukasawa, M., Watanabe, S., and Sathyendranath, S.: Oceanographic Basis of the Global Surface Distribution of Prochlorococcus Ecotypes, Science, 312, 918-921, 2006.

Bratbak, G., Heldal, G. M., Norland, S., and Thingstad, T. F.: Viruses as partners in spring bloom microbial trophodynamics, Appl. Environ. Microbiol., 56, 1400-1405, 1990.

Carpenter, E. J.: Marine Cyanobacterial symbioses, Biol. Environ., 102B, 1, 15-18, 2002.

Chavez, F. P., Buck, K. R., and Barber, R. T.: Phytoplankton taxa in relation to primary production in the Equatorial Pacific, DeepSea Res., 37, 11A, 1733-1752, 1990.

Claustre, H.: The trophic status of various oceanic provinces as revealed by phytoplankton pigment signatures, Limnol. Oceanogr., 39, 5, 1206-1210, 1994.

Claustre, H., Kerhervé, P., Marty, J. C., Prieur, L., Videau, C., and Hecq, J. H.: Phytoplankton dynamics associated with a geostrophic front: ecological and biogeochemical implications, J. Mar. Res., 52, 711-742, 1994.

Claustre, H. and Maritorena, S.: The many shades of ocean blue, Science, 302, 1514-1515, 2003.

Claustre, H. and Marty, J. C.: Specific phytoplankton biomasses and their relation to primary production in the tropical North Atlantic, Deep-Sea Res. I, 42, 8, 1476-1493, 1995.

Claustre, H., Sciandra, A., and Vaulot, D.: Introduction to the special section: bio-optical and biogeochemical conditions in the South East Pacific in late 2004 - the BIOSOPE cruise, Biogeosciences Discuss., 5, 605-640, 2008, http://www.biogeosciences-discuss.net/5/605/2008/.

Cottrell, M. T., Mannino, A., and Kirchman, D. L.: Aerobic anoxygenic phototrophic bacteria in the Mid-Atlantic Bight and the North Pacific gyre, Appl. Environ. Microbiol., 72, 1, 557-564, 2006. 
Dandonneau, Y., Deschamps, P. Y., Nicolas, J. M., Loisel, H., Blanchot, J., Montel, Y., Thieuleux, F., and Becu, G.: Seasonnal and interannual variability of ocean colour and composition of phytoplankton communities in the North Atlantic, Equatorial Pacific and South Pacific, Deep-Sea Res. II, 51, 303-318, 2004.

Dandonneau, Y., Montel, Y., Blanchot, J., Giraudeau, J., and Neveux, J.: Temporal variability in phytoplankton pigments, picoplankton and coccolithophores along a transect though the North Atlantic and tropical southwestern Pacific, Deep-Sea Res. I, 53, 4, 689-712, 2006.

Duarte, C. M., Agusti, S., and Agawin, N. S. R.: Response of a Mediterranean phytoplankton community to increased nutrient inputs: a mesocosm experiment, Mar. Ecol. Progress Ser., 195, 61-70, 2000a.

Duarte, C. M., Agusti, S., Gasol, J. M., Vaqué, D., and VazquezDominguez, E.: Effect of nutrient supply on the biomass structure of planktonic communities: an experimental test on a Mediterranean coastal community, Mar. Ecol. Progress Ser., 206, 87-95, 2000b.

Falkowski, P. G. and LaRoche, J.: Acclimation to spectral irradiance in algae, J. Phycol., 27, 8-14, 1991.

Garczarek, L. Dufresne, A., Rousvoal, S., West, N., Mazard, S., Marie, D., Claustre, H., Raimbault, P., Post, A., and Partensky, F.: High Vertical and Low Horizontal Microdiversity of Prochlorococcus Genotypes in the Mediterranean Sea in Summer, FEMS Microbiol. Ecol. doi:10.1111/j.15746941.2007.00297.x, 2006.

Gieskes, W. W. C., Kraay, G. W., Nontji, A., Setiapermana, D., and Sutomo, D.: Monsoonal alternation of a mixed and a layered structure in the phytoplankton of the euphotic zone of the Banda Sea (Indonesia): A mathematical analysis of algal pigment fingerprints, Netherlands J. Sea Res., 22, 123-137, 1988.

Goericke, R.: Bacteriochlorophyll- $a$ in the ocean: is anoxygenic bacterial photosynthesis important?, Limnol. Oceanogr., 47, 1, 290-295, 2002.

Goericke, R. and Repeta, D. J.: The pigments of Prochlorococcus marinus: the presence of divinyl chlorphyl $\mathrm{a}$ and $\mathrm{b}$ in a marine procaryote, Limnol. Oceanogr., 37, 2, 425-433, 1992.

Goericke, R. and Repeta, D. J.: Chlorophylls- $a$ and $b$ and divinyl chlorophylls- $a$ and $b$ in the open subtropical North Atlantic Ocean, Mar. Ecol. Progress Ser., 101, 3, 307-313, 1993.

Gómez, F., Claustre, H., Raimbault, P., and Souissi, S.: Two HighNutrient Low Chlorophyll phytoplankton assemblages: the tropical central Pacific and the offshore Perú-Chile Current, 4, 15351554, 2007.

Grob, C., Ulloa, O., Claustre, H., Alarcon, G., Huot, Y., and Marie, D.: Contribution of picoplankton to the particulate attenuation coefficient (cp) and organic carbon concentration (POC) in the eastern South Pacific, 4, 1461-1497, 2007.

Guillard, R. R. L., Murphy, L. S., Foss, P., and Liaaen-Jensen, S.: Synechococcus spp. as likely zeaxanthin-dominant ultraphytoplankton in the North Atlantic, Limnol. Oceanogr., 30, 2, 412-414, 1985.

Hardy, J., Hanneman, A., Behrenfield, M., and Horner, R.: Environmental biogeography of near-surface phytoplankton in the southeast Pacific ocean, Deep-Sea Res. I, 43, 10, 1647-1659, 1996.

Hooker, S. B., Van Heukelem, L., Thomas, C. S., Claustre, H., Ras, J., Barlow, R., Sessions, H., Schluter, L., Perl, J., Trees, C., Stuart, V., Head, H., Clementson, L., Fishwick, J.,
Llewellyn, C., and Aiken, J.: The second SeaWiFS HPLC Analysis Round-Robin Experiment (SeaHARRE-2), NASA, Goddard Space Flight Center, Maryland, Technical Memorandum NASA/TM-2005-212787, 112 pp., 2005.

Huot, Y., Babin, M., Bruyant, F., Grob, C., Twardowski, M. S., and Claustre, H. : Does chlorophyll- $a$ provide the best index of phytoplankton biomass for primary productivity studies?, Biogeosciences, 4, 853-868, 2007,

http://www.biogeosciences.net/4/853/2007/.

Jeffrey, S. W. and Vesk, M.: Introduction to marine phytoplankton and their pigment signatures, in: Phytoplankton pigment in oceanography: Guidelines to modern methods, edited by: Jeffrey, S. W., Mantoura, R. F. C., and Wright, S. W., UNESCO, 33-84, 1997.

Johnson, G. C. and McPhaden, M. J.: Interior pycnocline flow from the Subtropical to the Equatorial Pacific Ocean, J. Phys. Oceanogr., 29, 12, 3073-3089, 1999.

Johnson, Z. and Howd, P.: Marine photosynthetic performance forcing and periodicity for the Bermuda Atlantic Time Series, 1989-1995, Deep-Sea Res. I, 47, 8, 1485-1512, 2000.

Johnson, Z. I., Zinser, E. R., Coe A., McNulty N. P., Malcolm E., Woodward S., and Chisholm S. W.: Niche partitioning among Prochlorococcus ecotypes along Ocean-scale environmental gradients, Science, 311, 1737-1740, 2006.

Kolber, Z. S., Plumley, F. G., Lang, A. S., Beatty, J. T., Blankenship, R. E., VanDover, C. L, Vetriani, C., Koblizek, M., Rathgeber, C., and Falkowski, P. G.: Contribution of aerobic photoheterotrophic bacteria to the carbon cycle in the ocean, Science, 292, 24922495, 2001.

Lami, R., Cottrel, M. T., Ras, J., Ulloa, O., Obernosterer, I., Claustre, H., Kirchman, D. L., and Lebaron, P.: High abundances of aerobic anoxygenic photosynthetic bacteria in the South Pacific Ocean, Appl. Environ. Microbiol., 73, 13, 4198-4205, 2007.

Landry, M. R., Ondrusek, M. E., Tanner, S. J., Brown, S. L., Constantinou, J., Bidigare, R. R., Coale, K. H., and Fitzwater, S.: Biological response to iron fertilization in the eastern equatorial Pacific (IronEx II). I. Microplankton community abundances and biomass, Mar. Ecol. Progress Ser., 201, 27-42, 2000.

Larsen, A., Fonnes Flaten, G. A., Sandaa, R. A., Castberg, T., Thyrhaug, R., Erga, S. R., Jacquet, S., and Bratbak, G.: Spring phytoplankton bloom dynamics in Norwegian coastal waters: Microbial community sucession and diversity, Limnol. Oceanogr., 49, 1, 180-190, 2004.

Letelier, R. M., Karl, D. M., Abbott, M. R., and Bidigare, R. R.: Light driven seasonnal patterns of chlorophyll and nitrate in the lower euphotic zone of the North Pacific Subtropical Gyre, Limnol. Oceanogr., 49(2), 508-519, 2004.

Longhurst, A. R.: Ecological geography of the sea, Academic Press, London, 398 pp., 1998.

MacIntyre, H. L., Kana, T. M., Anning, T., and Geider, R.: Photoacclimation of photosynthesis irradiance response curves and photosynthetic pigments in microalgae and cyanobacteria, J. Phycol., 38, 17-38, 2002.

Mackey, M. D., Mackey, D. J., Higgins, H. W., and Wright, S. W.: CHEMTAX - a program for estimating class abundances from chemical markers: Application to HPLC measurements of phytoplankton, Mar. Ecol. Progress Ser., 144, 265-283, 1996.

Mahowald, N. M., Baker, A. R., Bergametti, G., Brooks, N., Duce, R. A., Jickells, T. D., Kubilay N., Prospero, J. M., 
and Tegen, I.: Atmospheric global dust cycle and iron inputs to the ocean, Global Biogeochem. Cy., 19, GB4025, doi:10.1029/2004GB002402, 2005.

Monger, B. C., Landry, M. R., and Brown, S. L.: Feeding selection of heterotrophic marine nanoflagellates based on the surface hydrophobicity of their picoplankton prey, Limnol. Oceanogr., 44, 8, 1917-1927, 1999.

Moore, L. R., Goericke, R., and Chisholm, S. W.: Comparitive physiology of Synechoccus and Prochlorococcus: influence of light and temperature on growth, pigments, fluorescence and absorptive properties, Mar. Ecol. Progress Ser., 116, 259-275, 1995.

Moore, L. and Chisholm S.W.: Photophysiology of the Marine Cyanobacterium Prochlorococcus: Ecotypic Differences among Cultured Isolates, Limnol. Oceanogr., 44, 3, 1, 628-638, 1999.

Morden, C. W. and Sherwood, A. R.: Continued evolutionary surprises among dinoflagellates, Proc. Natl. Acad. Sci. USA., 99, 18, 11 558-11 560, 2002.

Morel, A. and Berthon, J. F.: Surface pigments, algal biomass profiles and potential production of the euphotic layer: relationships reinvesitaged in view of remote sensing applications, Limnol. Oceanogr., 34, 1545-1562, 1989.

Morel, A. and Maritorena, S.: Bio-optical properties of oceanic waters: a reappraisal, J. Geophys. Res., 106, C4, 7163-7180, 2001.

Morel, A., Gentili, B., Claustre, H., Babin, M., Bricaud, A., Ras, J., and Tieche, F.: Optical properties of the "clearest" natural waters, Limnol. Oceanogr., 52, 1, 217-229, 2007.

O'Reilly, J. E., Maritorena, S., Mitchell, B. G., Siegel, D. A., Carder, K. L., Garver, S. A., Kahru, M., and McClain, C.: Ocean color chlorophyll algorithms for SeaWiFS, J. Geophys. Res., 103, C11, 24 937-24 954, 1998.

Parsons, T. R. and Strickland, J. D. H.: Discussion of spectrophotometric determination of marine plankton pigments with revised equations of as certaining chlorophyll- $a$ and carotenoids, J. Mar. Res., 21, 3, 155-163, 1963.

Partensky, F., Blanchot, J., Lantoine, F., Neveux, J., and Marie, D.: Vertical structure of picophytoplankton at different trophic sites of the tropical northeastern Atlantic Ocean, Deep-Sea Res. I, 43, 8, 1191-1213, 1996.

Partensky, F., Hess, W. R., and Vaulot, D.: Prochlorococcus, a Marine Photosynthetic Prokaryote of Global Significance, Microbiol. Mol. Biol. R., 63, 1, 106-127, 1999.

Prézelin, B. B., Hofmann, E. E., Mengelt, C., and Klinck, J. M.: The linkage between Upper Circumpolar Deep Water (UCDW) and phytoplankton assemblages on the west Antarctic Peninsula continental shelf, J. Mar. Res., 58, 165-202, 2000.

Raimbault, P., Garcia, N., and Cerrutti, F.: Distribution of inorganic and organic nutrients in the South Pacific Ocean. Evidence for long-term accumulation of organic matter in nitrogen-depleted waters, 4, 3041-3087, 2007.
Scharek, R., Latasa, M., Karl, D. M., and Bidigare, R. R.: Temporal variations in diatom abundance and downward vertical flux in the oligotrophic North Pacific gyre, Deep-Sea Res. I, 46, 1051-1075, 1999.

Signorini, S. R., McClain, C. R., and Dandonneau, Y.: Mixing and phytoplankton bloom in the wake of the Marquesas Islands, Geophys. Res. Lett., 26, 3121-3124, 1999.

Singler, H. R. and Villareal, T. A.: Nitrogen inputs into the euphotic zone by vertically migrating Rhizosolenia mats, J. Plankton Res., 27, 6, 545-556, 2005.

Stuart, V., Ulloa O., Alarcon, G., Sathyendranath, S., Major, H., Head, E. J. H., and Platt, T.: Bio-optical characteristics of phytoplankton populations in the upwelling system off the coast of Chile, Rev. Chil. Hist. Natl., 77, 87-105, 2004.

Twardowski, M. S., Claustre, H., Freeman, S. Stramski, D., and Huot, Y.: Optical Backscattering Properties of the "Clearest" Natural Waters, Biogeosciences Discuss., 4, 2441-2491, 2007, http://www.biogeosciences-discuss.net/4/2441/2007/.

Uitz, J., Claustre, H., Morel, A., and Hooker, S.: Vertical distribution of phytoplankton communities in open ocean: an assessment based on surface chlorophyll, J. Geophys. Res., 111, C08005, doi:10.1029/2005JC003207, 2006.

Van Heukelem, L. and Thomas, C. S.: Computer-assisted highperformance liquid chromatography method development with applications to the isolation and analysis of phytoplankton pigments, J. Chromatogr. A, 910, 31-49, 2001.

Venrick, E. L.: The distribution and significance of Richelia intracellularis Schmidt in the North Pacific Central Gyre, Limnol. Oceanogr., 19, 3, 437-445, 1974.

Vidussi, F., Claustre, H., Manca, B. B., Luchetta, A., and Marty, J. C.: Phytoplankton pigment distribution in relation to upper thermocline circulation in the eastern Mediterranean Sea during winter, J. Geophys. Res., 106, C9, 19939-19956, 2001.

Villareal, T. A., Joseph, L., Brzezinski, M. A., Shipe, R. F., Lipschultz, F., and Altabet, M. A.: Biological and chemical characteristics of the giant diatom Ethmodiscus (Bacillariophyceae) in the central north Pacific gyre, J. Phycol., 35, 896-902, 1999.

Wagener, T., Guieu, C., Losno, R., Bonnet S., and Mahowald, N.: Revisiting atmospheric dust export to the South Hemisphere ocean, Global Biogeochem. Cy., doi:10.1029/2007GB002984, in press, 2008.

Wright, S. W. and Jeffrey, S. W.: Fucoxanthin pigment markers of marine phytoplankton analysed by HPLC and HPTLC, Mar. Ecol. Progress Ser., 38, 259-266, 1987.

Yentsch, C. S. and Menzel, D. W.: A method for the determination of phytoplankton chlorophyll and phaeophytin by fluorescence, Deep-Sea Res., 10, 221-231, 1963. 